International Review of Research in Open and Distributed Learning Volume 16, Number 1

February - 2015

\title{
Trends in Distance Education Research: A Content Analysis of Journals 2009-2013
}
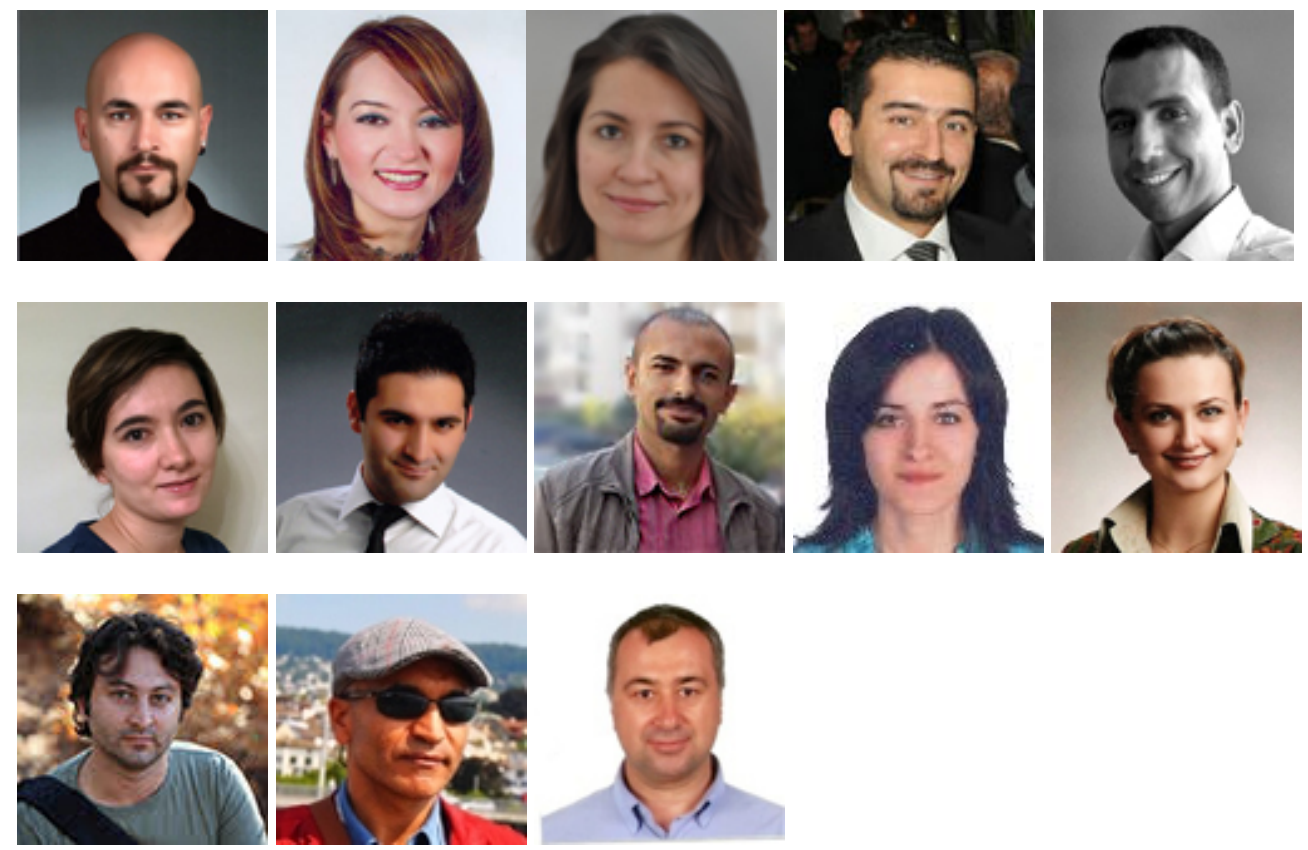

Aras Bozkurt, Ela Akgun-Ozbek, Sibel Yilmazel, Erdem Erdogdu, Hasan Ucar, Emel Guler, Sezan Sezgin, Abdulkadir Karadeniz, Nazife Sen-Ersoy, Nil Goksel-Canbek, Gokhan Deniz Dincer, Suleyman Ari, and Cengiz Hakan Aydin

Anadolu University, Turkey

\section{Abstract}

This study intends to explore the current trends in the field of distance education research during the period of 2009-2013. The trends were identified by an extensive review of seven peer reviewed scholarly journals: The American J ournal of Distance Education (AJ DE), Distance Education (DE), The European J ournal of Open, Distance and e-Learning (EURODL), The J ournal of Distance Education (J DE), The J ournal of Online Learning and Technology (J OLT), Open Learning: The J ournal of Open, Distance and e-Learning (OL) and The International Review of Research in Open and Distributed Learning (IRRODL). A total of 861 research 
articles was reviewed. Mainly content analysis was employed to be able to analyze the current research. Also, a social network analysis (SNA) was used to interpret the interrelationship between keywords indicated in these articles. Themes were developed and the content of the articles in the selected journals were coded according to categories derived from earlier studies. The results were interpreted using descriptive analysis (frequencies) and social network analysis. The reporting of the results were organized into the following categories: research areas, theoretical and conceptual frameworks, variables, methods, models, strategies, data collection and analysis methods, and the participants. The study also identified the most commonly used keywords, and the most frequently cited authors and studies in distance education. The findings obtained in this study may be useful in the exploration of potential research areas and identification of neglected areas in the field of distance education.

Keywords: Distance education trends; distance education issues; research evaluation; content analysis

\section{Introduction}

There has been a profound change globally, particularly in terms of scientific developments and social changes. One aspect of this is the way in which technology has become an essential part of our lives. The impact that this has had on society in general is becoming more and more visible, with the result that technology is now very much expected to be used in the proliferation of information. As a direct consequence of these expectations, there has been a parallel paradigm shift in education.

According to Harasim (2000), the invention of the Web technologies made online education increasingly accessible, open, flexible; allowed new pedagogical models to emerge and reasoned the revolution in digital knowledge age that enabled greater and faster human communication and collaboration and led to fundamentally new forms of economic activity that produced the knowledge economy and required basic changes in education. Educators embraced the revolution, and the increased educational opportunities and especially the new learning models that have emerged are now influencing education and society as a whole. The 21st century thus begins with a paradigm shift in attitudes towards online education. Online learning is no longer peripheral or supplementary, yet an integral part of mainstream society. Our new understanding of the very nature of learning has affected the definition, design, and delivery of education. Paradigm shift in education has resulted in: new modes of educational delivery, new learning domains, new principles of learning, new learning processes and outcomes and new educational roles and entities.

Distance education (DE) as a multidisciplinary field has reacted to these changes; it has and is still evolving and orienting itself to fulfill this demand. Thus, as the demands of educators and

This work is licensed under a $\underline{\text { Creative Commons Attribution } 4.0 \text { International License. }}$ 
learners evolve, it is crucial to understand and get a deeper insight of trends and issues in DE so as to keep abreast of these constant changes. This study was conducted in direct response to this demand and aims to help educators and researchers spot recent DE trends by studying written scholarly documents, that is to say to provide a comprehensive list of "mute evidence" (Hodder, 1994) in the field.

\section{Literature Review}

In recent years, research has been conducted to investigate DE research trends. One of the first studies to investigate trends in DE was carried out by Berge and Mrozowski (2001), who examined research literature in DE over a ten-year period from 1990 to 1999. Categorization of the articles ( $\mathrm{N}=890)$ was based on Sherry's (1996) ten research issues, namely redefining the roles of key participants, technology selection and adoption, design issues, strategies to increase interactivity and active learning, learner characteristics, learner support, operational issues, policy and management issues, equity and accessibility, and cost/ benefit trade-offs. According to the results obtained, it was seen that pedagogical themes such as design issues, learner characteristics, and strategies for active learning were the most frequent topics used in the field. Also, the most prevalent research methodology was descriptive methodology.

Lee, Driscoll and Nelson (2004) also examined research topics, methods and citation trends in four journals: The American J ournal of Distance Education (AJDE), the J ournal of Distance Education (J DE), Distance Education (DE) and Open Learning : The J ournal of Open, Distance and e-Learning (OL). Three hundred and eighty-three articles e-published between 1997 and 2002 were selected from these journals and they classified the articles into six themes: designrelated, development-related, management-related, evaluation-related, institutional and operational-related, and theory and research-related. The thematic analysis method was used to explore core meanings. The results of this research yielded six topics: general research topics, research specific topics, the research method, the statistical method used in experimental studies, a citation of the authors, and the cited books and articles/ chapters.

A series of studies were conducted by Zawacki-Richter to explore the DE research domain. The first study (Zawacki-Richter, 2009) used a Delphi technique to develop a classification of research areas. The second study (Zawacki-Richter, Bäcker and Vogt, 2009) identified gaps and priority areas and analyzed 695 articles published in five prominent DE journals between 2000 and 2008. The third study (Zawacki-Richter and von Prümmer, 2010) carried out an analysis of the impact of gender and collaboration patterns among researchers in research methods, research topics and research productivity.

In his study, Zawacki-Richter (2009) developed a categorization of research areas in DE and identified the most important and the most neglected research areas in DE. Having conducted an

This work is licensed under a Creative Commons Attribution 4.0 International License. 
extensive literature review and a Delphi study with expert responses from editorial board members from the major DE journals from September-December 2008, Zawacki-Richter identified 15 research areas which were organized into 3 broad categories. The participants of the study were 19 voluntary experts with an average of 27 years of professional experience in DE who had made significant contributions to DE literature. Based on the experts' responses, ZawackiRichter grouped the 15 research areas into three categories. In the second round of the Delphi study, presented in Table 1, each category was prioritized by the experts.

After comparing the results of the study with a previous study by Jegede (1994) in Australia, Zawacki-Richter concluded that the priority of DE research areas have not changed drastically, yet it was noted that innovations in online learning led to a shift from technology centered research to a research of management and change in DE institutions. It was noted that the emergence of online distance learning highlights a pressing need for educational institutions to embrace innovation and change. Delphi experts agreed that the areas of innovation and change and quality assurance should be prioritized as research areas while faculty support and professional development along with "Web 2.0 applications, mobile devices, and synchronous tools afford for teaching, learning, and assessment" also deserved further attention. 
Table 1

\title{
Classification of Research Areas in Distance Education (Zawacki-Richter et al., 2009)
}

\begin{abstract}
Macro level: Distance education systems and theories.
1. Access, equity, and ethics: The democratization of access to distance education afforded by new media and by finding ways to deliver high-quality education to those who have limited resources and poor infrastructure; issues that refer to the (sustainable) provision of distance education in developing areas. What is the impact of distance education (e.g., via mobile learning) on narrowing the digital divide and what is the role of ICT (information and communication technologies) and/or OER (open educational resources) in terms of access to education?

2. Globalization of education and cross-cultural aspects: Aspects that refer to the global external environment and drivers, the development of the global distance education market, teaching and learning in mediated global environments, and the implications for professional development.

3. Distance teaching systems and institutions: Distance education delivery systems, the role of institutional partnerships in developing transnational programmes, and the impact of ICT on the convergence of conventional education and distance education institutions (hybrid or mixed mode).

4. Theories and models: Theoretical frameworks for and foundations of distance education, e.g., the theoretical basis of instructional models, knowledge construction, interaction between learners, or the impact of social constructivism learning theories on distance education practice.

5. Research methods in distance education and knowledge transfer: Methodological considerations, the impact of distance education research and writing on practice, and the role of professional associations in improving practice. Literature reviews and works on the history of distance education are also subsumed within this area.
\end{abstract}

\section{Meso level: Management, organization, and technology.}

6. Management and organization: Strategies, administration, and organizational infrastructures and frameworks for the development, implementation, and sustainable delivery of distance education programmes. What is required for successful leadership in distance education? Distance education and policies relating to continuing education, lifelong learning, and the impact of online learning on institutional policies, as well as legal issues (copyright and intellectual property).

7. Costs and benefits: Aspects that refer to financial management, costing, pricing, and business models in distance education. Efficiency: What is the return on investment or impact of distance education programmes? What is the impact of ICT on the costing models and the scalability of distance education delivery? How can cost effective but meaningful learner support be provided?

8. Educational technology: New trends in educational technology for distance education (e.g., Web 2.0 applications or mobile learning) and the benefits and challenges of using OERs, media selection (e.g., synchronous vs. asynchronous media), technical infrastructure and equipment for online learning environments, and their opportunities for teaching and learning.

9. Innovation and change: Issues that refer to educational innovation with new media and measures to support and facilitate change in institutions (e.g., incentive systems for faculty, aspects referring to staff workloads, promotion, and tenure).

10. Professional development and faculty support: Professional development and faculty support services as a prerequisite for innovation and change. What are the competencies of online teachers and how can they be developed?

11. Learner support services: The infrastructure for and organization of learner support systems (from information and counselling for prospective students about library services and technical support to career services and alumni networks).

12. Quality assurance: Issues that refer to accreditation and quality standards in distance education. The impact of quality assurance and high quality learner support on enrolments and dropout/ retention, as well as reputation and acceptance of distance education as a valid form of educational provision.

Micro level: Teaching and learning in distance education.

13. Instructional design: Issues that refer to the stages of the instructional design process for curriculum and course development. Special emphasis is placed on pedagogical approaches for tutoring online (scaffolding), the design of (culturally appropriate) study material, opportunities provided by new developments in educational technology for teaching and learning (e.g. Web 2.0 applications and mobile devices), as well as assessment practices in distance education.

14. Interaction and communication in learning communities: Closely related to instructional design considerations is course design that fosters (online) articulation, interaction, reflection, and collaboration throughout the learning and teaching process. Special areas include the development of online communities, gender differences, and cross-cultural aspects in online communication.

15. Learner characteristics: The aims and goals of adult learners, the socioeconomic Background of distance education students, their different learning styles, critical thinking dispositions, and special needs. How do students learn online (learner behavior patterns, learning styles) and what competencies are needed for distance learning (e.g., digital literacy)?

Zawacki-Richter's study is limited to English speaking experts, but it is significant to note that the participants reflect the ideas of DE professionals across different countries and continents

This work is licensed under a Creative Commons Attribution 4.0 International License. 
(Australia, Brazil, Canada, China, Fiji, Germany, Ireland, New Zealand, South Africa, UK, and USA). Therefore, although the results may not be valid for some non-English speaking settings, the fact that the participants come from different schools of thought makes the study rigorous in reflecting the major research areas of study in $\mathrm{DE}$.

In their follow up study, Zawacki-Richter et al. (2009) used their typology of issues to categorize 695 articles, published between 2000 and 2008 in The American J ournal of Distance Education (AJDE), Distance Education (DE), The International Review of Research in Open and Distributed Learning (IRRODL), The J ournal of Distance Education (JDE) and Open Learning: The J ournal of Open, Distance and e-Learning (OL). The articles were drawn from a wide variety of topics within the scope of DE research. They concluded that issues about instructional design, interaction and communication patterns in computer-mediated communication, learner characteristics, and educational technology dominated DE research.

One of the major findings of this research was their attempt to tabulate the diversity of research methods employed in DE. Zawacki-Richter et al. (2009) found that qualitative research methods were more widely used than other methods. Another significant trend is collaboration among researchers. The researchers concluded that the proportion of single-authors was $44.2 \%$ in the period between 2000 and 2008. Another research by Mishra (1997) concerning the collaboration of authors concluded that $61.5 \%$ of articles were published by a single author between 1991 and 1996.

Zawacki-Richter and Anderson (2014) went one step further and provided a comprehensive survey on the state of online distance education as an independent field of inquiry, while also offering a clear orientation for future research. In their book Online Distance Education: Towards a Research Agenda these research areas were discussed by leading DE researchers to draw on their expert knowledge and professional experience to give an overview of the state of the art in each research area and derive research needs based on that. Zawacki-Richter and Anderson (2011), additionally, conducted a study to analyze the relationships and influences of $12 \mathrm{DE}$ journals using bibliographic description and social network analysis to investigate the structure and patterns of information exchange within the field of DE research.

\section{Purpose and Research Questions}

$\mathrm{DE}$ is prone to continuous change in line with developments in technology and learning sciences, a situation that opens the field up to new research areas in very short time spans. Moreover, recent developments in open educational resources and massive open online courses (MOOCs) have given the field a new dimension which has brought its own dynamics with it. Therefore, there is a need to mirror the DE field to be able to understand and interpret the new dynamics, namely DE trends. Berge and Mrozowski (2001) between 1990-1999 and Zawacki-Richter et al.

This work is licensed under a Creative Commons Attribution 4.0 International License. 
(2009) between 2000-2008 presented research trends in DE. Therefore, the year 2008 was chosen as cutoff date for this study and authors examined the articles published between 20092013 as a follow up research. The main goal of this study was to analyze the research articles published in seven widely accepted journals in the field to be able to explore the current trends in the field of DE research during the period 2009-2013. For this purpose the following research questions were considered:

What are the most frequent/ly

1. indicated keywords,

2. chosen research areas,

3. emphasized theoretical/conceptual backgrounds,

4. employed research designs,

5. used data collection instruments and data analysis techniques,

6. focused variables,

7. targeted population and/ or participant groups,

8. cited references,

9. cited authors

in DE research articles between 2009 and 2013?

\section{Methodology}

\section{Research Design}

For the purposes of the study, the authors chose to use content analysis to study empirical documentation. Content analysis has been defined as a systematic, replicable technique for compressing many words of text into fewer content categories based on explicit rules of coding (Berelson, 1952). Since content analysis is a method of analyzing written, verbal or visual communication messages which includes both qualitative and quantative approaches (Elo \& Kyngäs, 2008), it was deemed to be the most appropriate for the intent of this study. The authors developed and set the criteria for the themes to be studied and the content of articles in the selected journals was then coded according to these pre-set categories. Following the content analysis, the findings were reported using descriptive analysis. Later, a social network analysis

This work is licensed under a $\underline{\text { Creative Commons Attribution } 4.0 \text { International License. }}$ 
was employed to analyze keywords in the selected articles to achieve a deeper comprehension and distinguish the links between them.

\section{Sample}

Seven journals were reviewed for this study: The American Journal of Distance Education (AJDE), Distance Education (DE), European Journal of Open Distance and e- Learning (EURODL), Journal of Distance Education (JDE), Journal of Online Learning and Technology (J OLT), Open Learning: The J ournal of Open, Distance and e-Learning (OL), The International Review of Research in Open and Distributed Learning (IRRODL). The selection of the journals was based on a preliminary review of journals in DE and educational technology. In the first round, 82 journals were identified. The journals to be reviewed were filtered using the following criteria:

- a specific focus on DE and open and distance learning context,

- refereed journals that are indexed by prominent databases,

- a publication history of 10 years or more,

- publication of articles in English (with the exception of Journal of DE which also publishes a very limited number of articles in French).

Following the selection of the journals, a thorough review was made of all articles published between 2009-2013 ( $\mathrm{N}=1,225)$. Of these, 861 were identified as research articles and the others, that is to say 364, were identified as other (editorials, book reviews, interviews, concept papers, position papers, reflection papers, field notes, technical notes, etc.). For this study, only the research articles were used.

The research area classification schema that is used in this study is based on Zawacki-Richter's (2009) study, explained in the introduction and shown in Table 1. This research category and area schema was adopted since it is rigorous due to its being based upon the views of experts in the field of DE.

Categories related to methodology for coding largely follow those identified in Creswell (2012). When a study did not fit into the categories identified by Creswell, the name of the method that the writer of the article used was added into an existing category based on similarity of method with others in that category.

\section{Reliability}

To increase reliability, thirteen researchers who have the same background in the Distance Education Department at Anadolu University participated in this study. The researchers were trained before conducting the study and the pre-set categories were defined before the review process. Review of the articles took place in two rounds. Articles published annually were reviewed by two researchers in the first round and a different set of two researchers cross-checked and reviewed the selected articles again in the second round. Disagreed issues were discussed

This work is licensed under a Creative Commons Attribution 4.0 International License. 
Trends in Distance Education Research: A Content Analysis of Journals 2009-2013

Bozkurt, Akgun-Ozbek, Yilmazel, Erdogdu, Ucar, Guler, Sezgin, Karadeniz, Sen-Ersoy, Goksel-Canbek, Dincer, Ari, and Aydin

within the group and coded only after the researchers who had reviewed those articles reached a concensus.

The research question regarding research areas (Table 1) in DE was coded in the first round with 10 raters (2009: A-B; 2010: C-D; 2011: E-F; 2012: H-I; 2013: J-K). In the second round, the same raters (2009: L-M; 2010: O-P; 2011: Q-R; 2012: S-T; 2013: V-W) were assigned as pairs for different years. Inter-rater reliability for 2009, between rater A and L, was $\kappa=.740$; between B and $\mathrm{M}$, it was $\kappa=.714$. For 2010, between rater $\mathrm{C}$ and $\mathrm{O}$, it was $\kappa=.744$; between $\mathrm{D}$ and $\mathrm{P}$, it was $\kappa$ $=.760$. For 2011, between rater $\mathrm{E}$ and $\mathrm{Q}$, it was $\kappa=.813$; between $\mathrm{F}$ and $\mathrm{R}$, it was $\kappa=.783$. For 2012, between rater $\mathrm{H}$ and $\mathrm{S}$, it was $\kappa=.728$; between $\mathrm{I}$ and $\mathrm{T}$, it was $\kappa=.837$. For 2013, between rater $\mathrm{J}$ and $\mathrm{V}$, it was $\kappa=.842$; between $\mathrm{K}$ and $\mathrm{W}$, it was $\kappa=.826$.

Table 2

Cohen's Kappa Values for Inter-Coder Reliability

\begin{tabular}{lccccc}
\hline Rounds & \multicolumn{5}{c}{ Years } \\
\hline 1st & $\mathbf{2 0 0 9}$ & $\mathbf{2 0 1 0}$ & $\mathbf{2 0 1 1}$ & $\mathbf{2 0 1 2}$ & $\mathbf{2 0 1 3}$ \\
round & $\mathrm{A}$ and $\mathrm{L}$, & $\mathrm{C}$ and $\mathrm{O}$, & $\mathrm{E}$ and $\mathrm{Q}$, & $\mathrm{H}$ and $\mathrm{S}$, & $\mathrm{J}$ and $\mathrm{V}$, \\
& $\kappa=.74 \mathrm{O}$ & $\kappa=.744$ & $\kappa=.813$ & $\kappa=.728$ & $\kappa=.842$ \\
\hline $\mathbf{2}^{\text {nd }}$ & $\mathrm{B}$ and $\mathrm{M}$, & $\mathrm{D}$ and $\mathrm{P}$, & $\mathrm{F}$ and $\mathrm{R}$, & $\mathrm{I}$ and $\mathrm{T}$, & $\mathrm{K}$ and $\mathrm{W}$, \\
round & $\kappa=.714$ & $\kappa=.760$ & $\kappa=.783$ & $\kappa=.837$ & $\kappa=.826$ \\
\hline
\end{tabular}

Altman (1991) proposed that the extent of agreement can be qualified as poor $(<0.20)$, fair $(0.21$ to 0.40 ), moderate ( 0.41 to 0.60$)$, good ( 0.61 to 0.80 ) and very good ( 0.81 to 1.00$)$. Thus, the reliability of raters A-L, B-M, C-O, D-P, F-R and H-S can be considered as acceptable. Besides, the reliability of raters E-Q, I-T, J-V and K-W can be considered as quite acceptable.

\section{Findings and Discussion}

For this study, 1,225 articles were examined (Table 3). A total of 364 articles were excluded and 861 articles were included to content analysis and examined through the criteria determined. 
Trends in Distance Education Research: A Content Analysis of Journals 2009-2013

Bozkurt, Akgun-Ozbek, Yilmazel, Erdogdu, Ucar, Guler, Sezgin, Karadeniz, Sen-Ersoy, Goksel-Canbek, Dincer, Ari, and Aydin

Table 3

J ournals and Number of Articles

\begin{tabular}{|c|c|c|c|c|c|c|}
\hline JOURNALS & 2009 & 2010 & 2011 & 2012 & 2013 & TOTAL (N) \\
\hline American Journal of Distance Education (AJDE) & 29 & 25 & 24 & 25 & 31 & 134 \\
\hline Distance Education (DE) & 32 & 25 & 33 & 31 & 28 & 149 \\
\hline $\begin{array}{l}\text { European Journal of Open, Distance and E- } \\
\text { Learning (EURODL) }\end{array}$ & 16 & 12 & 12 & 30 & 23 & 93 \\
\hline Journal of Distance Education (JDE) & 29 & 31 & 23 & 13 & 10 & 106 \\
\hline Journal of Online Learning and Teaching (JOLT) & 59 & 76 & 54 & 29 & 45 & 263 \\
\hline $\begin{array}{l}\text { Open Learning: The Journal of Open, Distance } \\
\text { and e-Learning (OL) }\end{array}$ & 26 & 27 & 27 & 17 & 25 & 122 \\
\hline $\begin{array}{l}\text { The International Review of Research in Open } \\
\text { and Distance Learning (IRRODL) }\end{array}$ & 85 & 39 & 79 & 75 & 80 & 358 \\
\hline ALL ARTICLES & 276 & 235 & 252 & 220 & 242 & 1225 \\
\hline EXCLUDED* & 110 & 66 & 89 & 41 & 58 & 364 \\
\hline INCLUDED & 166 & 169 & 163 & 179 & 184 & 861 \\
\hline
\end{tabular}

\section{Keywords Indicated}

The first finding of the research is based on a descriptive keyword analysis with an assumption that keywords indicated in the articles provide a holistic reflection of the research paper topics. In this study a total of 4,088 keywords (633 field specific and 3,455 research related) were included in the study and ranked according to their frequency. Later, the field and the research specific keywords were also analyzed separately.

Figure 1 shows the field specific keywords. As can be observed in Figure 1, the term "distance education" is a generic term used to define this field. Another interesting finding concerns the word "online" which is used as a descriptive term. It may be concluded that DE is getting more dependent on the online technologies and there is a shift from traditional learning environments or media to online learning environments or media. As a final remark, the term open and distance learning (ODL) has appeared in increasing frequency especially in the last two years in congruence with a decrease in the use of the term $\mathrm{DE}$ in the same time span. This change from $\mathrm{DE}$ to ODL as a generic term might be a consequence of the openness movement in general and the use of OER, MOOCs, Web 2.0 and open spirit on networked Web environments in particular. 
Trends in Distance Education Research: A Content Analysis of Journals 2009-2013

Bozkurt, Akgun-Ozbek, Yilmazel, Erdogdu, Ucar, Guler, Sezgin, Karadeniz, Sen-Ersoy, Goksel-Canbek, Dincer, Ari, and Aydin

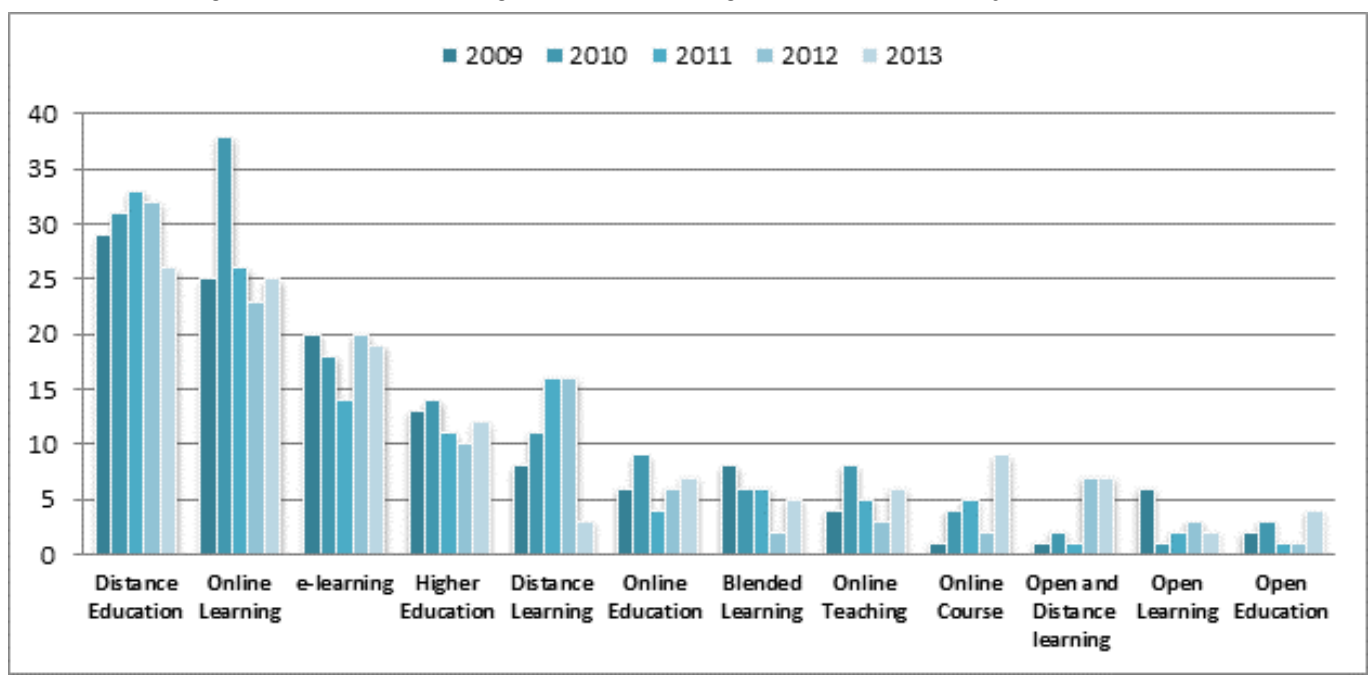

Figure 1. Field specific keywords (N=633).

The second finding is about the use of research specific keywords (Figure 2). For this analysis, all keywords were collected from papers and ranked according to their frequency of appearance in the articles in general. As The J ournal of Distance Education doesn't provide keywords for the articles, researchers defined keywords for the articles in this journal. For this analysis, all the keywords were ranked and the top 40 keywords were included in this research. Keywords that shared the same rank were ordered alphabetically.

This descriptive keyword analysis demonstrates a five-year trend from many points of view, such as "OERs" as a movement, "mobile learning" as a technology based approach and "collaborative learning" as a pedagogy which are all noteworthy. Links implied between keywords is a further area deserving attention, for instance, the terms OERs, MOOCs and Web 2.0; interaction and social presence; CoI (community of inquiry) and social networks may be related to one another and could be evaluated as a group of keywords rather than terms having solo meanings. 


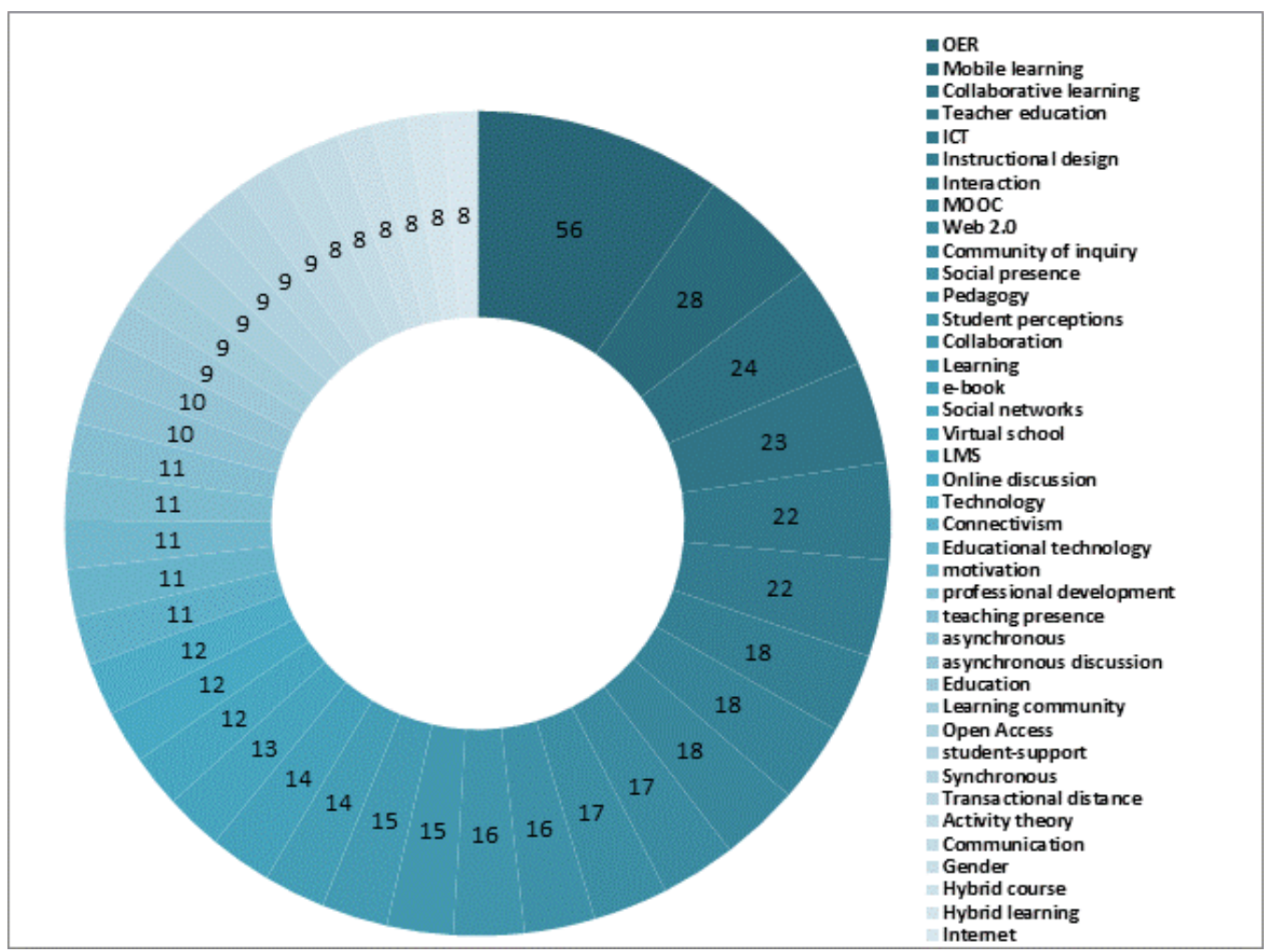

Figure 2. Top 40 keywords indicated more often than others $(\mathrm{N}=3455)$.

The frequency count presents a descriptive analysis of the top 40 keywords. On the other hand, to understand and quantify the influence and importance of the relationship among these keywords, social network analysis (SNA) was conducted for the top 40 keywords and a complete network model was visualized based on their relations using centrality distribution.

SNA is the mapping and measuring of relationships and flows between people, groups, organizations, computers, or other information and knowledge processing entities (Krebs, 2002, para. 1). The main goal of SNA is detecting and interpreting patterns of social ties among actors (De Nooy, Mrvar and Batagelj, 2011, p. 5). These networks usually visualized in a social network diagram, where nodes are represented as points and ties are represented as lines to conceptualize and to analyze them.

For this analysis, the relationships of top 40 keywords (nodes) were identified on a 40x40 matrix and then these nodes were tied to each other manually by using SNA software. Following that, the raw data was visualized applying centrality measure analysis. As a result of this analysis, 40 nodes and 914 ties (edges) were observed. In terms of node betweenness centrality, used to measure the load and importance of a node, the keywords "learning" and "education" appeared as important nodes (Figure 3). This finding also confirms Zawacki-Richter and Anderson's (2014, p. 9) 
Trends in Distance Education Research: A Content Analysis of Journals 2009-2013

Bozkurt, Akgun-Ozbek, Yilmazel, Erdogdu, Ucar, Guler, Sezgin, Karadeniz, Sen-Ersoy, Goksel-Canbek, Dincer, Ari, and Aydin

conclusion that the majority of published research deals with topics and issues with regard to "teaching" and "learning" processes in online distance education.

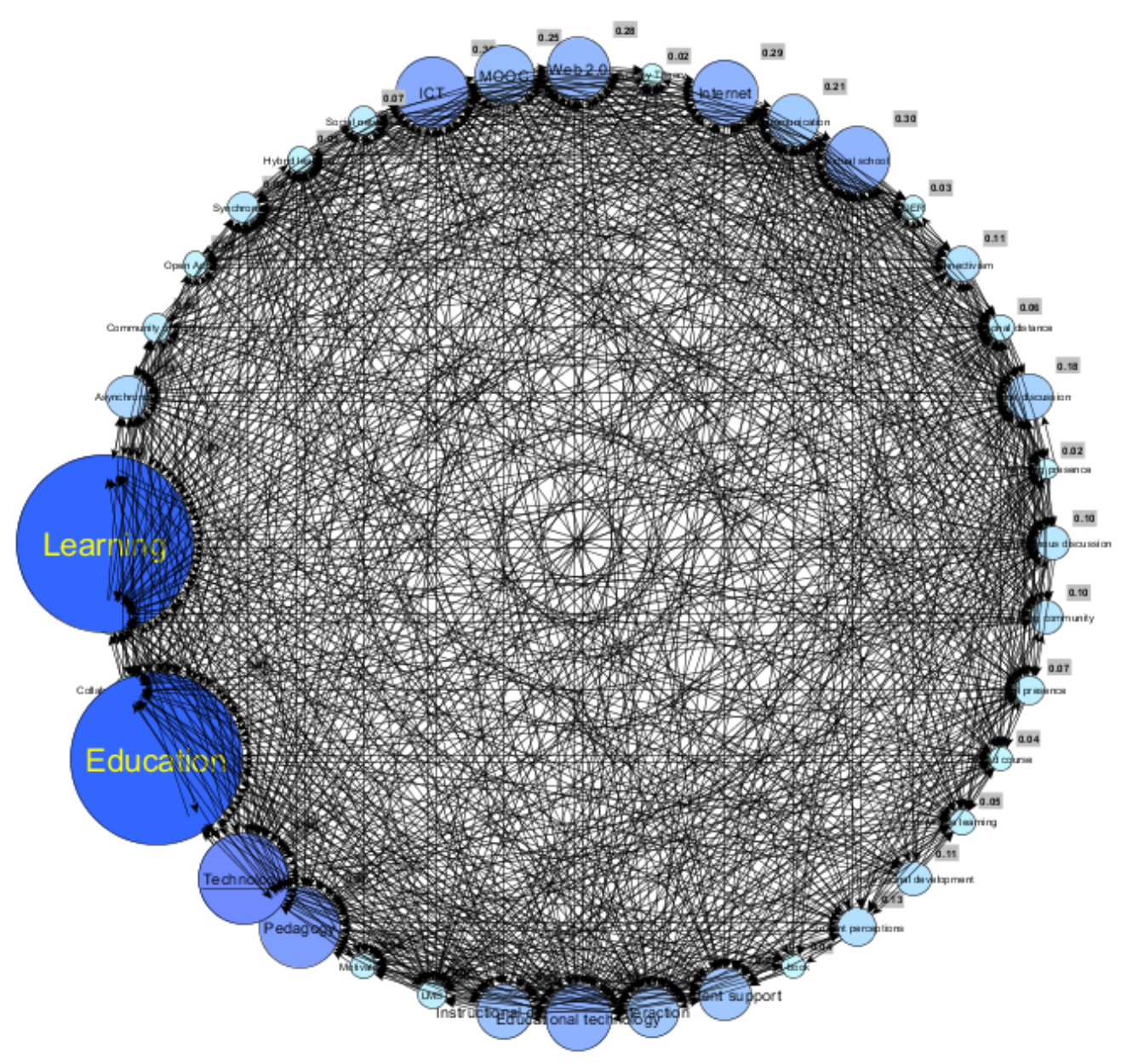

Figure 3. A circular node betweenness centrality diagram.

\section{Research Areas}

As has been mentioned, in this study, the classification developed by Zawacki-Richter (2009) is used to define the research areas in DE. Upon analysis of the count numbers highlighted per year in the meta-levels of DE research classification, it can be seen that there is a strong imbalance between research areas and high over-representation of the micro level perspective. This finding also demonstrates similarities to previous research findings (Zawacki-Richter et al., 2009) and confirms the results of their content analysis. It is also interesting to note that interaction and communication in learning communities (13\%), learner characteristics (12\%), and instructional design (11\%) from micro levels and educational technology (15\%) from meso level constitute 51\%

This work is licensed under a $\underline{\text { Creative Commons Attribution } 4.0 \text { International License. }}$ 
Trends in Distance Education Research: A Content Analysis of Journals 2009-2013

Bozkurt, Akgun-Ozbek, Yilmazel, Erdogdu, Ucar, Guler, Sezgin, Karadeniz, Sen-Ersoy, Goksel-Canbek, Dincer, Ari, and Aydin

of all research areas (Figure 4). The meso level finding for "Educational technology" also confirms that DE is strongly related to technological developments. In addition to this peak in meso level, the peaks in micro level reflect the very nature of DE research. For instance, the result for "interaction and communication in learning communities" is based on web-based learning environments and social network sites; "learner characteristic" is a consequence of individual and learner centered approaches; and "instructional design" is a result of the emerging digital learning environments.

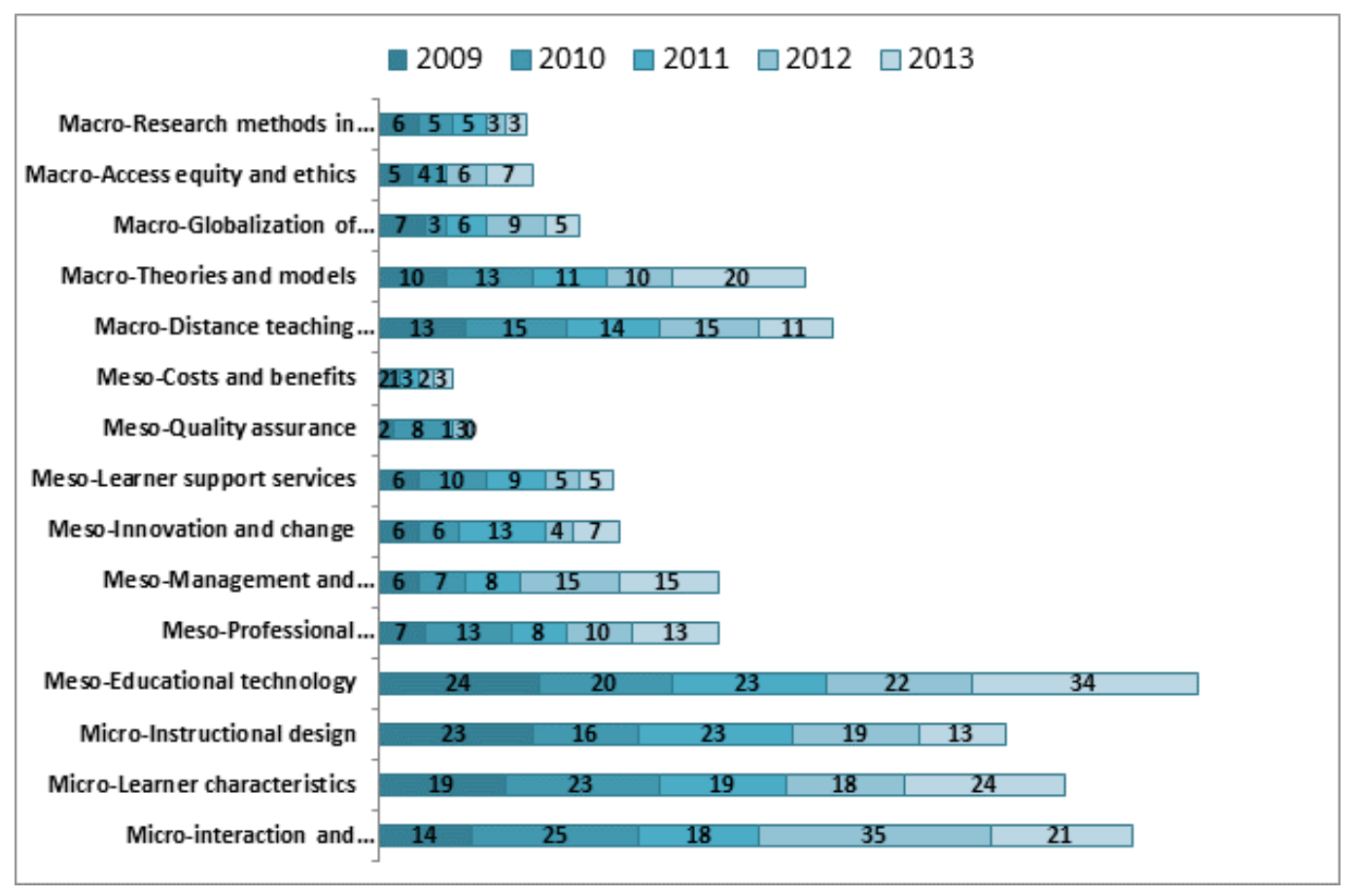

Figure 4. Classification of research areas.

\section{Theoretical/Conceptual Backgrounds}

Since every research study should have adequate theoretical or conceptual backgrounds, investigating the theoretical/conceptual backgrounds indicated in the research articles can provide an insight about the current trends on what kinds of topics the researches are focusing on in any field. Therefore, in this study the theories and/or concepts stated in the articles were gathered and the top ten theories/concepts were ranked according to their frequency. Theories/ concepts that share the same rank are ordered alphabetically.

Those findings dealing with the theoretical/conceptual background of the articles indicate the nature of the new learning paradigm of $21^{\text {st }}$ century that focuses more on the learner rather than instructor or administrator. CoI as a theory of knowledge formation and the process of scientific

This work is licensed under a $\underline{\text { Creative Commons Attribution } 4.0 \text { International License. }}$ 
inquiry rank as the most frequently used theoretical perspectives. Collaborative learning emphasizing active interaction between learners follows theoretical perspectives in the rankings. Constructivism, which argues that humans generate knowledge and meaning from interactions between their experiences and their ideas, is in third place. Connectivism as a learning theory for the digital age, though it has a very recent history, is also in third place and this may be a result of the growing impact of technology and networks on learning.

It is clear that theories that explain how learning occurs on networks (connectivism, social networking) through collaboration in a community (community of inquiry, collaborative learning, social learning theory, activity theory) by interaction, based on immersion (critical thinking) and experience (constructivism, problem based learning, social constructivism theory) are favored by DE researchers. In addition to this, researchers focused on delivery methods (blended learning, mobile learning) that use multimedia elements (cognitive load theory) in which psychological distance (transactional distance theory) and presence (social presence theory) are important as well as learner dedication (self-regulated learning, self-directed learning, motivation theory). From this perspective, design (instructional design theories) for effective and efficient learning gained importance. After all, it wouldn't be correct to attribute one single dominant theory that reflects theoretical trend in $\mathrm{DE}$, but it would be a better approach to evaluate them as a whole since each theory intersects or overlaps at some points.

On the other hand, Table 4 also shows that DE research is still, naturally, based on the concepts and the theories derived from the field of education. However, DE practice uses concepts, principles, models and theories of many other fields, such as engineering, communication, management, sociology and psychology. Therefore, it, most probably, would not be wrong to say that as DE researchers we must widen our search for theoretical/conceptual base to other fields than education and bring their concepts and theories into our field. That might help us develop the maturity of DE as a scientific field of study.

Table 4

Theoretical/Conceptual Background

\begin{tabular}{ccl|ccl}
\hline $\mathbf{R}^{*}$ & $\mathbf{F}^{* *}$ & \multicolumn{1}{c|}{ THEORY } & $\mathbf{R}^{*}$ & $\mathbf{F}^{* *}$ & \multicolumn{1}{c}{ THEORY } \\
\hline $\mathbf{1}$ & 22 & Community of Inquiry & $\boldsymbol{8}$ & 7 & Cognitive Load Theory \\
$\mathbf{2}$ & 16 & Collaborative Learning & $\boldsymbol{8}$ & 7 & Motivation Theory \\
$\mathbf{3}$ & 15 & Constructivism & $\boldsymbol{8}$ & 7 & Problem Based Learning \\
$\mathbf{3}$ & 15 & Connectivism & $\boldsymbol{8}$ & 7 & Self-directed Learning \\
$\mathbf{4}$ & 14 & Blended Learning & $\boldsymbol{8}$ & 7 & Social Constructivism Theory \\
$\mathbf{4}$ & 14 & Transactional Distance Theory & $\mathbf{8}$ & 7 & Social Learning Theory \\
$\mathbf{5}$ & 11 & Mobile Learning & $\mathbf{9}$ & 6 & Social Networking \\
$\mathbf{6}$ & 10 & Activity Theory & $\mathbf{1 0}$ & 5 & Critical Thinking \\
$\mathbf{6}$ & 10 & Social Presence Theory & $\mathbf{1 0}$ & 5 & Instructional Design Theories \\
$\mathbf{7}$ & 8 & Self-regulated Learning & & & \\
\hline$R^{*}:$ Rank, F**:Frequency & & &
\end{tabular}

This work is licensed under a $\underline{\text { Creative Commons Attribution } 4.0 \text { International License. }}$ 


\section{Research Designs Employed}

Similar to many other fields, in a DE research study we might employ a quantitative, qualitative, or mixed research design. Table $5 \mathrm{~A}$ presents what kinds of research design categories researchers in the field of DE preferred over the last five years. Table 5B and 5C provide the preferences on yearly bases. As shown in these tables the researchers in DE mostly conducted qualitative (47\%) and quantitative (37\%) studies, and just a few employed mixed (16\%) designs.

Zawacki-Richter et al. (2009) reported rates of $29.1 \%$ quantitative, $19.9 \%$ qualitative, $12.9 \%$ mixed and 38.1\% other researches for 2000-2008 research trends $(\mathrm{N}=695)$. When comparing the results of 2000-2008 with 2009-2013, it may be seen that there has been a shift in the preference to qualitative and quantitative research design while mixed research design remains the same.

\section{Table 5A}

Percentage Of Research Methods Between 2009-2013

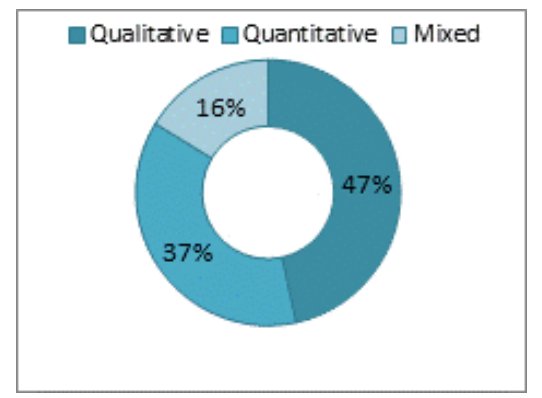


Trends in Distance Education Research: A Content Analysis of Journals 2009-2013

Bozkurt, Akgun-Ozbek, Yilmazel, Erdogdu, Ucar, Guler, Sezgin, Karadeniz, Sen-Ersoy, Goksel-Canbek, Dincer, Ari, and Aydin

Table 5B

Bar Chart Of Research Methods (Percentage Was Calculated Separately For Each Year)

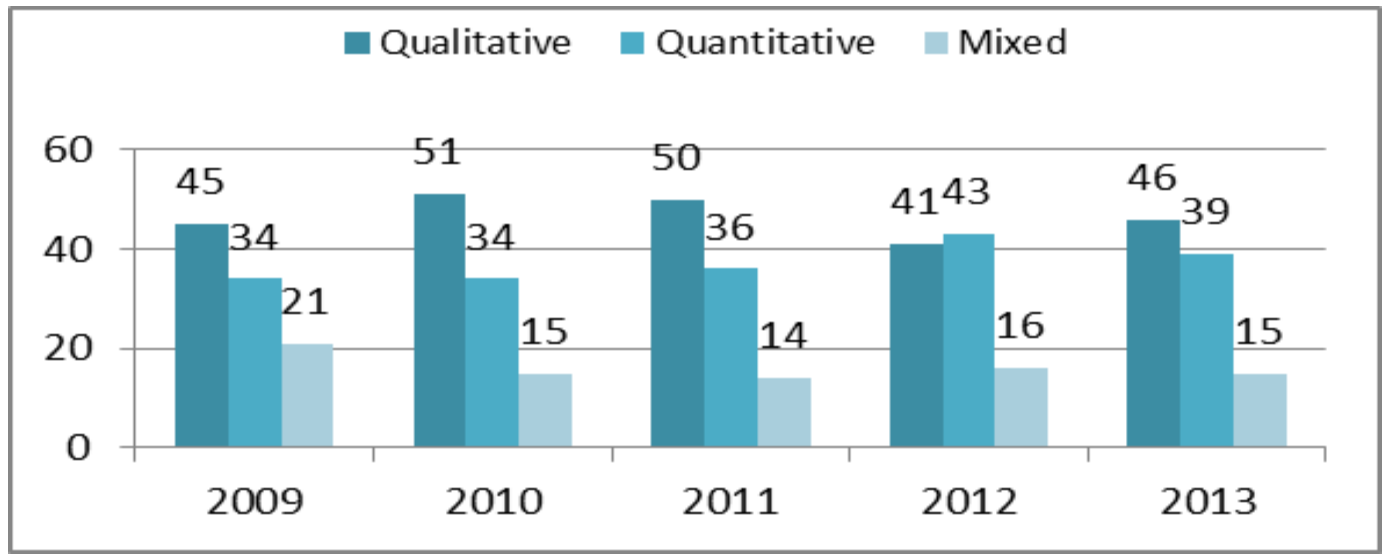

Table 5C

Line Chart Of Research Methods (Percentage Was Calculated Separately For Each Year)

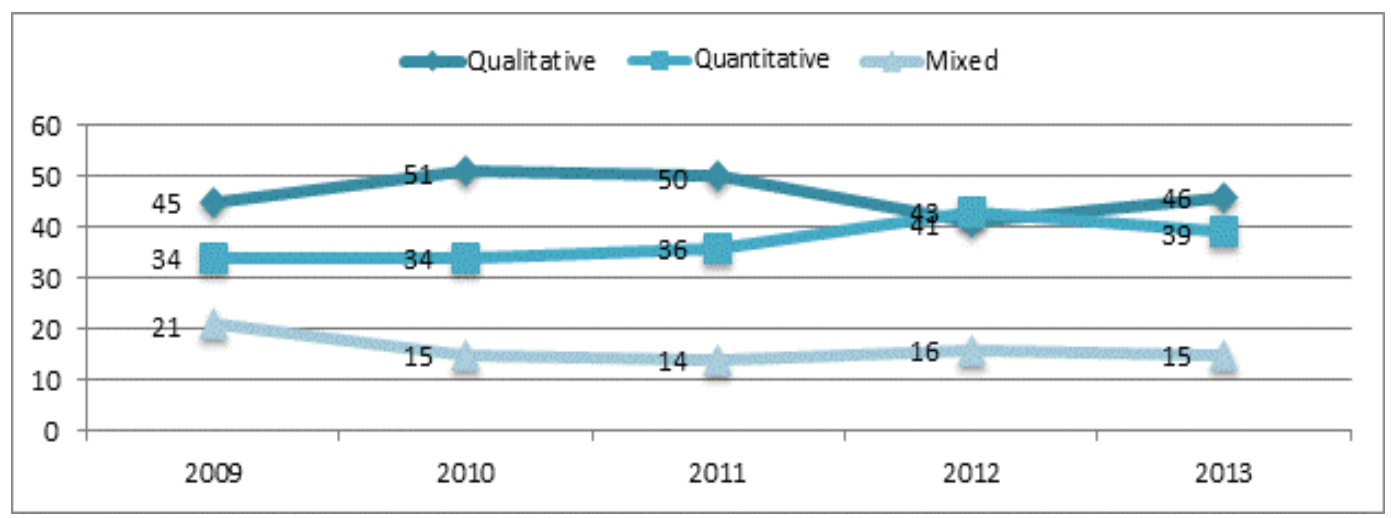

As an extension of the previous findings, this section of the content analysis presents the DE trends regarding research methodology (designs). Of all qualitative research designs, case studies (66\%) that focus on a descriptive, exploratory or explanatory analysis of a person, group or event stand out. Design-based research (9\%), phenomenology (7\%), action research (5\%), grounded theory (4\%), ethnography (3\%), content analysis (2\%), meta synthesis (1\%), narrative (1\%), 
historical (1\%) and heuristic (1\%) research models constitute $44 \%$ of the research models while case studies constitute $66 \%$ of all qualitative research design (Table 6). Berge and Mrozowski (2001) also reported that case study is the most preferred qualitative research design model (12.58\%) between 1990 and 1999.

Of all quantitative research design models, a great majority of studies preferred survey (58\%) as a basic descriptive research model. The use of a correlational (29\%) model that demonstrates the relationship between variables and the experimental (11\%) model used to test cause-and-effect relationships between variables hold the next ranking positions. Finally, meta-analysis (2\%) is seen to constitute a minor part of quantitative research design (Table 6). This data reveals that there is a need to conduct more quantitative correlational and experimental researches to understand and dig deeper into DE.

These findings exhibit similarities with Berge and Mrozowski's (2001) study for the research trends of 1990-1999. They reported a percentage of $74.83 \%$ descriptive, $6.63 \%$ correlational, $5.96 \%$ experimental researches, all of which were quantitative research design models, and $12.58 \%$ case study, a qualitative research design model $(\mathrm{N}=890)$.

Based on these data, it can be assumed that most of the quantitative DE researches are descriptive statistics which show or summarize sample data rather than inferential statistics which are used to test hypotheses and make estimations using sample data. This finding also supports and demonstrates a similarity to Panda's (1992) conclusion for Indian distance education literature. He reported that most studies were descriptive surveys or experimental studies with poor methodological footing.

Of all the mixed research design models, the exploratory (55\%) model, in which researchers interpret how quantitative results build on initial qualitative results, and the explanatory (31\%) model, in which researchers interpret how qualitative results help to explain initial quantitative results, constitute the majority of preferred research models. Convergent parallel (8\%), embedded (4\%) and multiphase (2\%) follow as the other mixed research models that are preferred by the researchers (Table 6).

Saba (2000) reported that, in contrast to pure experimental researches, DE goes beyond the narrow confines of experimentation and as a consequence began to use new methods in both qualitative and quantitative forms. These findings confirm Saba and also demonstrate a radical decrease in experimental research when compared to research conducted after the $50 \mathrm{~s}$.

It is also interesting that in qualitative (case studies), quantitative (survey) and mixed studies (exploratory), one dominant research model has been used. However, assuming that DE is an interdisciplinary field, a wide spectrum of research models may be used.

All in all, the findings obtained in this research reveal some interesting facts. In contrast to the modern paradigm, the world in which we live is not bipolar, but the research nature of $\mathrm{DE}$ 
basically evolves around qualitative and quantitative research designs. On the other hand, within a post-modern perspective, more mixed research designs in which qualitative and quantitative data collection methods are used may be employed.

Table 6

Research Designs and Models

\begin{tabular}{|c|c|c|c|c|c|c|c|c|c|c|c|c|c|c|c|c|}
\hline & & & & & & & & & & & & & & & & \\
\hline 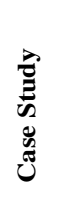 & 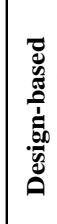 & & 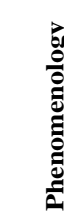 & & 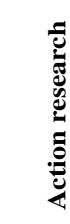 & & 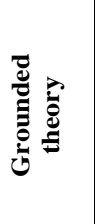 & 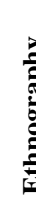 & & 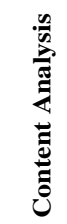 & & 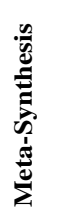 & 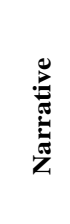 & 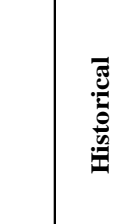 & & 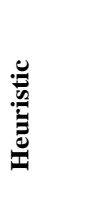 \\
\hline$\% 66$ & & 99 & & 67 & $\% 5$ & & $\begin{array}{l}\% 4 \\
\end{array}$ & & 63 & $\% 2$ & & $\% 1$ & $\% 1$ & $\% 1$ & & $\% 1$ \\
\hline & & & & & & & & & $\begin{array}{l}\text { itati } \\
\mathrm{V}=2\end{array}$ & & & & & & & \\
\hline & & & 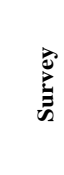 & & & & & & 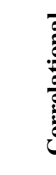 & & & & . & |ֶّ & 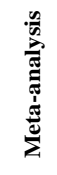 & 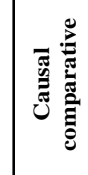 \\
\hline & & & $\% 58$ & & & & & & $\%$ & & & & $\%$ & & $\% 2$ & $\% 0$ \\
\hline Longi & adinal & & & ross-sect & & & Predic & & Com & & $\begin{array}{l}\text { Relatio } \\
\text { nship }\end{array}$ & \begin{tabular}{|r}
$\operatorname{Exp}$ \\
$\mathrm{n}$
\end{tabular} & & $\begin{array}{c}\text { Quasi- } \\
\text { experiment } \\
\text { al } \\
\end{array}$ & & \\
\hline 䞤 & 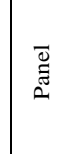 & 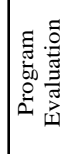 & 总 & 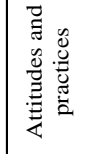 & 离 & 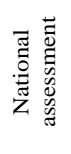 & & & & & & & & & & \\
\hline & & & & & & & & & $=1$ & & & & & & & \\
\hline $\begin{array}{c}E \\
s\end{array}$ & eqlora & & & $\begin{array}{l}\text { Explane } \\
\text { sequen }\end{array}$ & & & $\begin{array}{l}\text { onverge } \\
\text { parallel }\end{array}$ & & & nbedde & & Mul & iphase & Trans & form & tive \\
\hline & $\% 5$ & & & $\% 3$ & & & $\% 8$ & & & $\% 4$ & & & 02 & & $\% 0$ & \\
\hline
\end{tabular}

\section{Data Collection Tools and Strategies Used}

The data collection instruments were also investigated in this study. As one can easily interpret by looking at Figure 5, the surveys, interviews and document analyses are the most preferred tools in the DE studies. A further analysis has shown that in the quantitative studies, the researchers most frequently used questionnaires and in the qualitative studies they preferred document analyses and interviews. 


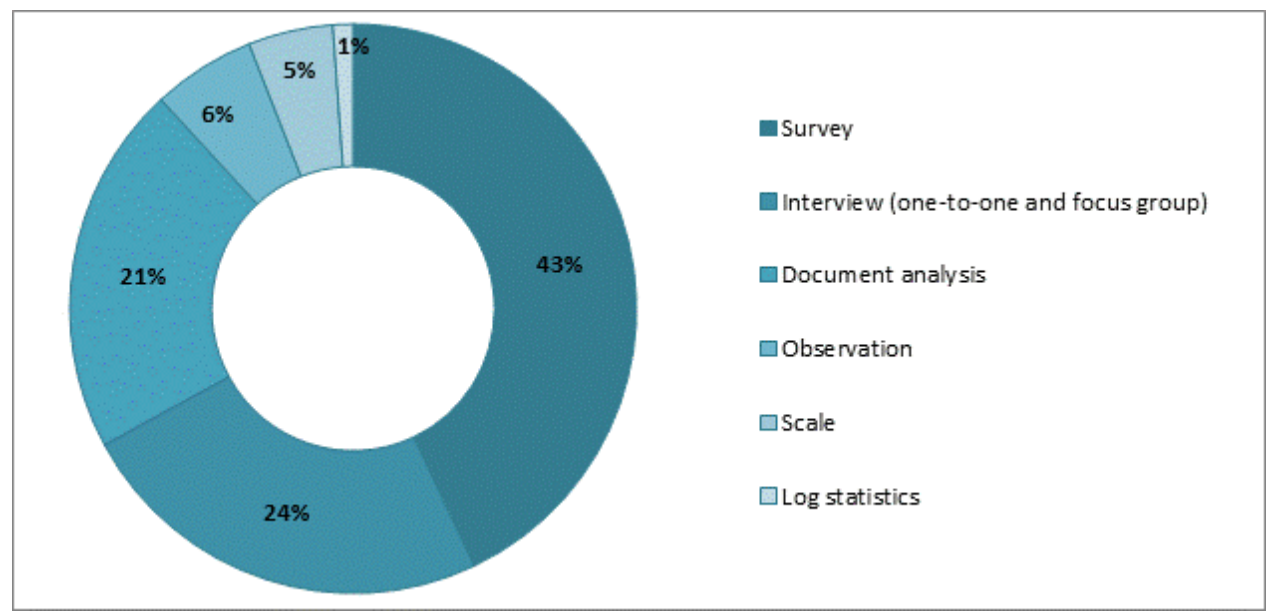

Figure 5. Data collection (instruments).

Davies, Howell and Petrie (2010) presented trends in research and scholarship between 1998 and 2007. They reported that the most frequently used data collection tools were survey (qualitative and quantitative) $(\mathrm{N}=194)$, interviews $(\mathrm{N}=128)$, existing artifacts (document analysis) $(\mathrm{N}=59)$, observations $(\mathrm{N}=17)$, researcher created assessments $(\mathrm{N}=16)$, existing test scores $(\mathrm{N}=16)$ and standardized assessments $(\mathrm{N}=15)$. When compared, it is clear that there is a strong similarity with current findings.

However, it was interesting to note that log statistics were not used as much as they should have been since one of the latest and hottest topics discussed in the field is the learner analytics and use of available data to be able to get an insight about learner behaviors in online learning environments and to help them offer better, more customized learning opportunities.

\section{Data Analysis Techniques Employed in the Studies}

Table 7 presents the number of the data analysis techniques that were explicitly reported in the investigated articles. This was one of the most difficult analysis due to the fact that there were quite a number of articles that did not clearly inform about the data analysis technique(s) used, and also some, including those mixed method studies, comprised a variety of techniques. Despite these difficulties, the analysis has shown interesting findings.

As can be observed in Table 7, one half of the quantitative studies included descriptive statistics (51\%) and mainly used variability, central tendency and relative standing tests. Nonetheless, a majority of the researchers ( $\mathrm{N}=72$ ) reported that they used descriptive statistics but didn't report which one of them was employed. In terms of inferential statistics (49\%) parametric tests such as variance analysis, $\mathrm{t}$-test, correlation, factor analysis, regression analysis, reliability analysis and structural equation modeling were extremely (85\%) preferred while only in a few (15\%) of the 
articles that included quantitative studies, non-parametric tests such as Wilcoxon test, Mann Whitney-U, Kruskal Wallis test, chi-square and Friedman's two way analysis were employed.

Qualitative interpretive analysis generally uses content, thematic and discourse analysis in which raw qualitative data is transcripted, coded, categorized and interpreted. These findings demonstrate a similar trend in terms of quantitative statistical tests when compared to Davies, Howell and Petrie's (2010) research regarding trends in distance education scholarship at research universities in North America between 1998 and 2007. They reported that most of the studies in their sample used descriptive data analysis predominantly.

Table 7

Tests and Analyses

\begin{tabular}{|c|c|c|c|c|c|}
\hline \multicolumn{6}{|c|}{$\begin{array}{c}\text { QUANTITATIVE } \\
\text { Statistical tests } \\
\end{array}$} \\
\hline \multirow{2}{*}{\multicolumn{2}{|c|}{ Descriptive (51\%) }} & \multicolumn{4}{|c|}{ Inferential (49\%) } \\
\hline & & \multicolumn{2}{|l|}{ Parametric (85\%) } & \multicolumn{2}{|c|}{ Non-parametric (15\%) } \\
\hline $\begin{array}{l}\text { Variability } \\
\text { (Variance-Standard Deviation- Range) }\end{array}$ & 163 & $\begin{array}{l}\text { Variance analysis } \\
\text { (ANOVA/MANOVA/MANCOVA) }\end{array}$ & 71 & Wilcoxon Test & 16 \\
\hline Central Tendency (mean-median-mode) & 108 & t-test & 52 & Mann Whitney U & 15 \\
\hline Descriptive statistics (not specified) & 72 & Correlation (Pearson) & 49 & Kruskal Wallis Ttest & 12 \\
\hline \multirow[t]{4}{*}{ Relative Standing (percentage/ z-score) } & 11 & $\begin{array}{l}\text { Factor Analysis } \\
\text { (Confirmatory/Exploratory) }\end{array}$ & 48 & Chi-square & 6 \\
\hline & & Regression analysis & 41 & $\begin{array}{l}\text { Friedman's two way } \\
\text { analysis }\end{array}$ & 2 \\
\hline & & Reliability analysis (Cronbach's Alpha) & 24 & & \\
\hline & & Structural Equation Modeling (SEM) & 3 & & \\
\hline & & & & & \\
\hline \multicolumn{6}{|c|}{ Interpretive Analysis (N=155) } \\
\hline Content analysis & & & & & 76 \\
\hline Thematic analysis & & & & & 74 \\
\hline Discourse analysis & & & & & 5 \\
\hline
\end{tabular}

\section{Variables Focused in the Studies}

Variables reported in the research studies examined were coded into main categories and ranked by frequency of appearance. 
Trends in Distance Education Research: A Content Analysis of Journals 2009-2013

Bozkurt, Akgun-Ozbek, Yilmazel, Erdogdu, Ucar, Guler, Sezgin, Karadeniz, Sen-Ersoy, Goksel-Canbek, Dincer, Ari, and Aydin

Table 8

Variables Focused Most Often in the Articles Examined

\begin{tabular}{ccl|cll}
\hline $\boldsymbol{R}^{*}$ & $\mathbf{F}^{* *}$ & VARIABLES & $\boldsymbol{R}^{*}$ & $\mathbf{F}^{* *}$ & \multicolumn{1}{c}{ VARIABLES } \\
\hline 1 & 53 & Perception & 9 & 14 & Effectiveness \\
2 & 43 & Satisfaction & 9 & 14 & Self-efficacy \\
3 & 39 & Gender & 10 & 13 & Collaboration \\
4 & 30 & Interaction & 11 & 12 & Communication \\
5 & 25 & Motivation & 12 & 11 & Delivery \\
6 & 21 & Age & 13 & 10 & Academic-performance \\
6 & 21 & Participation & 13 & 10 & Impact \\
7 & 18 & Attitude & 13 & 10 & Social-presence \\
$\boldsymbol{8}$ & 16 & Experience & & & \\
\hline$R^{*}:$ Rank, $F^{* *}:$ Frequency & & &
\end{tabular}

As can be seen in Table 8, variables usually focus on the feelings, emotions and behaviour of the learners. 'Satisfaction' and learner perception' are the most often focused variables about learners' emotions and feelings while 'gender' and 'age' are demographic non-parametric variables that have been examined more than other demographics in the investigated studies. These results can easily be linked to increasing attention to learners, their individual differences and the learner-centered approaches.

\section{Population and/or Participant Groups}

The research question regarding participants reveals interesting facts. As can be seen in Figure 6, participants of the studies examined are mostly undergraduate students (31\%), post graduate students (10\%) and academicians (10\%). The fact that a total of $51 \%$ constitutes higher education also explains why the field specific keyword (higher education) ranks fourth in the list (Figure 1). This data reveals that DE focuses largely on higher education and there are only a few studies conducted in K-12 settings. An important portion of the researchers reported that their target groups were teachers (10\%) and students (7\%); on the other hand, researchers didn't specify from which education level they came. Adult learners (4\%), administrators (4\%) and K-12 students (3\%) appear in the list, respectively. 
Trends in Distance Education Research: A Content Analysis of Journals 2009-2013

Bozkurt, Akgun-Ozbek, Yilmazel, Erdogdu, Ucar, Guler, Sezgin, Karadeniz, Sen-Ersoy, Goksel-Canbek, Dincer, Ari, and Aydin

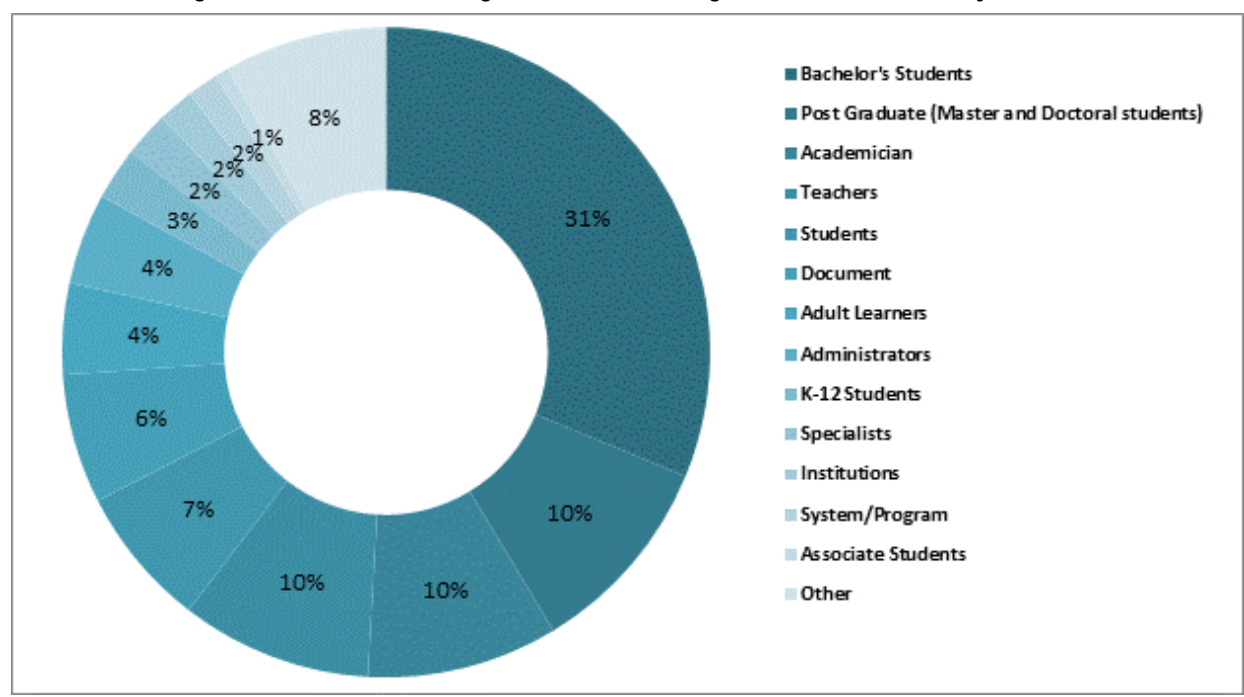

Figure 6. Target groups and participants.

In connection with these findings, $\mathrm{DE}$ education has roots in lifelong learning philosophy and covers formal, informal and non-formal learning, a finding which reveals that any age or occupation area can be a target group of these researches. On the other hand, K-12 students representing the formal education level prior to higher education and adult learners representing the latter education or learning process following higher education constitutes only $7 \%$ of total target groups. One explanation for the connections may be that it is more convenient to work with students from higher education since the researchers work in the same institutions. However, K12 is another setting in which DE is getting popularity (Lips, 2010; Queen \& Lewis, 2011). It was interesting to find that the research studies have not reached the expected level in K-12 settings, yet. One easily can predict that there will be more DE research in $\mathrm{K}-12$ settings in near future.

\section{Authors Cited Most Often}

In this part of this research, leading contributors in the field were determined in terms of the number of citations (Table 9). The total number of citations was 53,800. A total of 105 authors who have been cited at least 30 times are included in the table. Authors that share the same rank are ordered alphabetically.

It was quite interesting to note that UNESCO is $38^{\text {th }}$ on the list. It may mean that as an institution, UNESCO has a key role for DE and lifelong learning. A full list of the most cited authors ( $\mathrm{N}=105)$ is given in Appendix A. In contrast to some researches (Lee et al., 2004), to identify their significant impact to the field, not only first authors but also second, third and other co-authors were counted with an assumption that every author contributes to these works. Therefore, one should assume that collaborative works are more advantageous than solo works since the authors who have more collaborative works counted more than once in Table 9. 
Table 9

List of Most Cited Authors (Top 20)

\begin{tabular}{|l|l|l|l|l|l|l|l|l|}
\hline $\mathbf{R}^{*}$ & $\mathbf{F}^{* *}$ & \multicolumn{1}{|c|}{ Author } & $\boldsymbol{R}^{*}$ & $\mathbf{F}^{* *}$ & \multicolumn{1}{|c|}{ Author } & $\boldsymbol{R}^{*}$ & $\mathbf{F}^{* *}$ & \multicolumn{1}{|c|}{ Author } \\
\hline $\mathbf{1}$ & 520 & GARRISON, D.R. & $\mathbf{8}$ & 129 & SWAN, K. & $\mathbf{1 5}$ & 94 & ARBAUGH, J.B. \\
\hline $\mathbf{2}$ & 405 & ANDERSON, T. & $\mathbf{9}$ & 109 & ROVAI, A.P. & $\mathbf{1 6}$ & 90 & WENGER, E. \\
\hline $\mathbf{3}$ & 208 & MOORE, M.G. & $\mathbf{1 0}$ & 105 & ALLEN, I.E. & $\mathbf{1 7}$ & 88 & CLEVELAND-INNES, M \\
\hline $\mathbf{4}$ & 207 & ARCHER, W. & $\mathbf{1 1}$ & 103 & SIEMENS, G. & $\mathbf{1 8}$ & 81 & WILEY, D. \\
\hline $\mathbf{5}$ & 145 & SEAMAN, J. & $\mathbf{1 2}$ & 102 & DOWNES, S. & $\mathbf{1 9}$ & 79 & KANUKA, H. \\
\hline $\mathbf{6}$ & 135 & SHEA, P. & $\mathbf{1 3}$ & 101 & BONK, C.J. & $\mathbf{2 0}$ & 77 & SALMON, G. \\
\hline $\mathbf{7}$ & 129 & ROURKE, L. & $\mathbf{1 4}$ & 100 & GUNAWARDENA, C.N. & & & \\
\hline$R^{*}:$ Rank, $F^{* *}$ Frequency & \multicolumn{7}{|l}{} \\
\hline
\end{tabular}

Another result we obtained from these findings is common citation mistakes. It is important to cite references properly as well as to explain the research process in detail in order to help readers reading and to show respect to the researchers who contributed to the relevant study and to the field. It was observed that researchers whose name and surname consist of three parts (e.g. D. R., Garrison) or who have names of Far East origin (e.g. Chih-Hsiung Tu) were usually cited incorrectly. To give an example, in some papers D.R. Garrison is cited as Garrison, D. R., Garrison, D., or Garrison, R. and Chih-Hsiung Tu is cited as Tu, C.H., Tu, C-H., or Tu, C. Though not a research trend in itself, this problem is one of the points that made the analysis of the citation trends quite difficult.

\section{References Cited Most Often}

This part of the content analysis regarding citation trends presents the most cited works (articles, books, web sites, etc.) within the articles analyzed in the study. We believe that this list presents a comprehensive citation trend and may help researchers as a reference guide and as a reading list for those who study in this field (Table 10). This table was created by filtering 28,500 references that have been cited at least 10 times. Studies sharing the same rank were ordered by the publication date and if two studies had the same rank and publication date, they were ordered alphabetically. Older studies were ranked at the end and newer studies are ranked at the beginning. References were also categorized according to their type (article, book, book chapter, etc.). 
Trends in Distance Education Research: A Content Analysis of Journals 2009-2013

Bozkurt, Akgun-Ozbek, Yilmazel, Erdogdu, Ucar, Guler, Sezgin, Karadeniz, Sen-Ersoy, Goksel-Canbek, Dincer, Ari, and Aydin

Table 10

\section{The Reference List of Most Cited Studies (Top 15)}

\begin{tabular}{|c|c|c|c|}
\hline$R^{*}$ & $F * *$ & $T * * *$ & References \\
\hline 1 & 62 & A & $\begin{array}{l}\text { Garrison, D. R., Anderson, T., \& Archer, W. (1999). Critical inquiry in a text-based environment: Computer conferenc } \\
\text { in higher education. The internet and higher education, 2(2), 87-105. }\end{array}$ \\
\hline 2 & 53 & B & Vygotsky, L. S. (1980). Mind in society: The development of higher psychological processes. Harvard University Press \\
\hline 3 & 51 & B & Moore, M. G. \& Kearsley, G. (1996). Distance education: A Systems View. Canada: Wadsworth. \\
\hline 4 & 43 & A & Moore, M. G. (1989). Editorial: Three types of interaction. American Journal of Distance Education, 3(2), 1-7. \\
\hline 5 & 40 & $\mathrm{C}$ & $\begin{array}{l}\text { Moore, M. G. (1993). Theory of transactional distance. In D. Keegan (Ed.), Theoretical principles of distance educatio } \\
\text { (p 22-38) New York: Routledge. }\end{array}$ \\
\hline 6 & 35 & B & Jean. Lave, \& Wenger, E. (1991). Situated learning: Legitimate peripheral participation. Cambridge University Press. \\
\hline 6 & 35 & B & Patton, M. Q. (1980). Qualitative evaluation and research methods. SAGE Publications, inc. \\
\hline 7 & 34 & $\mathrm{R}$ & $\begin{array}{l}\text { Means, B., Toyama, Y., Murphy, R., Bakia, M., \& Jones, K. (2009). Evaluation of Evidence-Based Practices in Onlint } \\
\text { Learning: A Meta-Analysis and Review of Online Learning Studies. US Department of Education. }\end{array}$ \\
\hline 7 & 34 & $\mathrm{R}$ & $\begin{array}{l}\text { Allen, I. E., \& Seaman, J. (2008). Staying the Course: Online Education in the United States, 2008. Sloan Consortium, } \\
\text { Newburyport. }\end{array}$ \\
\hline 7 & 34 & A & $\begin{array}{l}\text { Garrison, D. R., \& Arbaugh, J. B. (2007). Researching the community of inquiry framework: Review, issues, and futur } \\
\text { directions. The Internet and Higher Education, 10(3), 157-172. }\end{array}$ \\
\hline 7 & 34 & A & $\begin{array}{l}\text { Anderson, T., Liam, R., Garrison, D. R., \& Archer, W. (2001). Assessing teacher presence in a computer conferencing } \\
\text { context. Journal of Asynchronous Learning Networks, 5(2), 1-17. }\end{array}$ \\
\hline 7 & 34 & B & Salmon, G. (2000). E-moderating: The key to teaching and learning online. Psychology Press. \\
\hline 8 & 33 & B & $\begin{array}{l}\text { Garrison, D. R., \& Anderson, T. (2003). E-learning in the 21st century: A framework for research and practice. Taylol } \\
\text { Francis. }\end{array}$ \\
\hline 9 & 32 & W & $\begin{array}{l}\text { Siemens, G. (2004). Connectivism: A learning theory for the digital age. Retrieved from } \\
\text { http://www.elearnspace.org/Articles/connectivism.htm }\end{array}$ \\
\hline 10 & 31 & B & Wenger, E. (1998). Communities of practice: Learning, meaning, and identity. Cambridge University Press. \\
\hline 11 & 30 & $\mathrm{R}$ & $\begin{array}{l}\text { Allen, I. E., \& Seaman, J. (2010). Learning on Demand: Online Education in the United States, 2009. Sloan Consortiu } \\
\text { Newburyport. }\end{array}$ \\
\hline 12 & 28 & $\mathrm{R}$ & $\begin{array}{l}\text { Watson, J., Gemin, B., Ryan, J., \& Wicks, M. (2009). Keeping Pace with K-12 Online Learning: An Annual Review of } \\
\text { State-Level Policy and Practice, 2009. Evergreen Education Group. }\end{array}$ \\
\hline 12 & 28 & A & $\begin{array}{l}\text { Tallent-Runnels, M. K., Thomas, J. A., Lan, W. Y., Cooper, S., Ahern, T. C., Shaw, S. M., \& Liu, X. (2006). Teaching } \\
\text { courses online: A review of the research. Review of educational research, 76(1), 93-135. }\end{array}$ \\
\hline 12 & 28 & A & $\begin{array}{l}\text { Garrison, D. R., Anderson, T., \& Archer, W. (2001). Critical thinking, cognitive presence, and computer conferencing } \\
\text { distance education. American Journal of distance education, 15(1), 7-23. }\end{array}$ \\
\hline 12 & 28 & B & Yin, R. K. (1984). Case study research: Design and methods. SAGE Publications, inc. \\
\hline 13 & 27 & A & $\begin{array}{l}\text { Garrison, D. R., \& Cleveland-Innes, M. (2005). Facilitating cognitive presence in online learning: Interaction is not } \\
\text { enough. The American Journal of Distance Education, 19(3), 133-148. }\end{array}$ \\
\hline 14 & 24 & A & $\begin{array}{l}\text { Downes, S. (2007). Models for sustainable open educational resources. Interdisciplinary Journal of Knowledge and } \\
\text { Learning Objects, 3, 29-44. }\end{array}$ \\
\hline 15 & 23 & B & $\begin{array}{l}\text { Organisation for Economic Co-operation and Development. (2007). Giving knowledge for free: The emergence of oper } \\
\text { educational resources. OECD Publishing. }\end{array}$ \\
\hline \multicolumn{4}{|c|}{$R^{*}:$ Rank, $F^{* *}: F r e q u e n c y, T^{* * *}:$ Type (A: Article, B:Book, BL: Bulletin, C:Chapter, P: Paper, R: Report, W: Web Page) } \\
\hline
\end{tabular}

This work is licensed under a Creative Commons Attribution 4.0 International License. 
Trends in Distance Education Research: A Content Analysis of Journals 2009-2013

Bozkurt, Akgun-Ozbek, Yilmazel, Erdogdu, Ucar, Guler, Sezgin, Karadeniz, Sen-Ersoy, Goksel-Canbek, Dincer, Ari, and Aydin

\section{Summary and Future Implications}

The results of this study reveal research trends and issues in DE emerging from scholarly publishing in seven prestigious journals. This study intends to present the current situation and provides a research direction for future research. The results can be summarized as follows. The generic term defining the field is "distance education" and another term "open and distance learning" has been used more and more as a consequence of the paradigm shift in education. The analysis of research specific keywords clearly indicates that DE demonstrates quick responses to emerging research topics. A holistic analysis of these keywords through social network analysis demonstrates that "learning" is the major topic in the field naturally. Open education resources (OERs) and mobile learning are new topics over the last five years DE researchers also focused on along with older topics, such as collaborative learning and teacher training.

The analysis of research areas portrays that educational technology from meso level, interaction and communication in learning communities, learner characteristics, and instructional design from micro levels are the most studied areas and constitute $51 \%$ of all fifteen research areas. Another result obtained through this study is that DE researchers employ different theoretical frameworks to explain and explore the DE field which also reflects the interdisciplinary nature of the field.

In terms of methodology, $\mathrm{DE}$ usually preferred qualitative, quantitative, or mixed research designs, respectively. Most of the qualitative studies used case study, quantitative studies used survey, and mixed studies used exploratory and explanatory research models. It can be also seen that qualitative researches preferred interviews (one-to-one and focus group), document analysis and observation while quantitative researches used questionnaires and scales to collect data. In the quantitative research studies, descriptive and inferential statistics were used almost equally. In the qualitative research, content and thematic analysis to interpret the data collected were generally preferred. Variables focused in the studies are usually concerned with learners' feelings, emotions and behaviors. Gender and age seem to be indispensable demographic variables of the studies. The main participants of these research studies still appeared to be learners in higher education, but there is a trend of focusing more on participants from the $\mathrm{K}-12$ settings.

In the final part of the study, the most cited authors and references were presented. In addition to providing leading researchers and important references, descriptive analysis of citation trends proved once again that DE uses knowledge of the past and present to be able to foresee the future.

Regarding the results of this study, the following implications can be taken into consideration for future researches:

- There are many terms defining the DE field. Even though they all look similar, they reflect unique aspects of the field. Thus, researchers need to select appropriate field specific terms that reflect the core of the study. However, it seems the term 'open and distance learning' is a

This work is licensed under a $\underline{\text { Creative Commons Attribution } 4.0 \text { International License. }}$ 
better name for our field of study since it reflects the core assumptions of the field: openness, accessibility, flexibility, massiveness, and quality learning opportunities to all.

- This study presented the most and the least studied research areas in the field. Considering that DE is a system, those neglected areas should be studied more in order to contribute to and improve the field. The authors of the present paper believe further study into why some research areas appear to be less popular would contribute richly to future research. The studies should not focus on only general characteristics of the learners, such as gender and age, but also various individual differences including cognitive processes, learning strategies, cultural differences. Additionally, we need studies examining the learning processes in informal, non-formal learning environments as well as OERs and MOOCs to be able to provide better learning opportunities. Bringing concepts, principles, models and theories from a variety of fields - especially from those that we use in DE practices often - might be beneficial for the development of the field. Especially, graduate students must be encouraged to use theoretical/conceptual backgrounds from different fields. For instance, business management field is a rich field of study that might help enlighten some of the issues of our field such as business models for MOOCs, OERs, recognition of prior learning.

- As an interdisciplinary field, we believe that rather than using specific research designs and models, researchers may use a variety of them to understand and to delve more deeply into the area. Especially mixed designs might help scientific development of the field. It is seen that participants and target groups are generally adult learners from higher education. However, we believe that research that targets K12 students might be conducted more considering the increasing use of e-learning in K12 settings.

This work is licensed under a Creative Commons Attribution 4.0 International License. 
Trends in Distance Education Research: A Content Analysis of Journals 2009-2013

Bozkurt, Akgun-Ozbek, Yilmazel, Erdogdu, Ucar, Guler, Sezgin, Karadeniz, Sen-Ersoy, Goksel-Canbek, Dincer, Ari, and Aydin

\section{References}

Altman, D. G. (1991). Practical statistics for medical research. London: Chapman \& Hall.

Berelson, B. (1952). Content analysis in communication research. Glencoe, Ill: Free Press.

Berge, Z. L., \& Mrozowski, S. (2001). Review of research in distance education, 1990 to 1999. American J ournal of Distance Education, 15(3), 5-19.

Creswell, J . W. (2012). Educational research: Planning, conducting and evaluating quantitative and qualitative research. Boston, MA: Pearson Education.

Davies, R., Howell, S., \& Petrie, J . (2010). A review of trends in distance education scholarship at research universities in North America, 1998-2007. The International Review Of Research In Open And Distance Learning, 11(3), 42-56.

De Nooy, W., Mrvar, A., \& Batagelj, V. (2011). Exploratory social network analysis with Pajek (Vol. 27). Cambridge University Press.

Elo, S., \& Kyngäs, H. (2008). The qualitative content analysis process. J ournal of Advanced Nursing, 62(1), 107-115.

Harasim, L. (2000). Shift happens: Online education as a new paradigm in learning. The Internet and Higher Education, 3(1), 41-61.

Hodder, I. (1994). The interpretation of documents and material culture. Thousand Oaks etc.: Sage.

J egede, O. J . (1994). Distance education research priorities for Australia: A study of the opinions of distance educators and practitioners. Distance Education, 15(2), 234-253.

Krebs, V. (2000). Social network analysis, a brief introduction. Retrieved from http://www.orgnet.com/sna.html

Lee, Y., Driscoll, M. P., \&Nelson, D. W. (2004). The past, present, and future of research in distance education: Results of a content analysis. The American J ournal of Distance Education, 18(4), 225-241.

Lips, D. (2010, J anuary 10). How online learning is revolutionizing K- 12 education and benefiting students. Backgrounder, 2356.

Mishra. S. (1997). A critical analysis of periodical literature in distance education. Indian J ournal of Open Learning, 6(1\&2), 39-53.

This work is licensed under a Creative Commons Attribution 4.0 International License. 
Trends in Distance Education Research: A Content Analysis of Journals 2009-2013

Bozkurt, Akgun-Ozbek, Yilmazel, Erdogdu, Ucar, Guler, Sezgin, Karadeniz, Sen-Ersoy, Goksel-Canbek, Dincer, Ari, and Aydin

Panda, S. (1992). Distance educational research in India: Stock-taking, concerns and prospects. Distance Education, 13(2), 309- 26.

Queen, B., \& Lewis, L. (2011). Distance education courses for public elementary and secondary school students: 2009-10 (NCES 2012-009). U.S. Department of Education, National Center for Education Statistics.

Saba, F. (2000). Research in distance education: A status report. The International Review of Research in Open and Distance Learning, 1(1).

Sherry, L. (1996). Issues in distance learning. International J ournal of Educational Telecommunications, 1(4), 337-65.

Zawacki-Richter, O. (2009). Research areas in distance education: a Delphi study. International Review of Research in Open and Distance Learning, 10(3).

Zawacki-Richter, O., \&Anderson, T. (2011). The geography of distance education-bibliographic characteristics of a journal network. Distance Education, 32(3), 441-456.

Zawacki-Richter, O., \&Anderson, T. (2014). Online distance education: Towards a research agenda. Edmonton, Canada: AU Press.

Zawacki-Richter, O., \& von Prümmer, C. (2010). Gender and collaboration patterns in distance education research. Open Learning, 25(2), 95-114.

Zawacki-Richter, O., Bäcker, E. M., \&Vogt, S. (2009). Review of distance education research (2000 to 2008): Analysis of research areas, methods, and authorship patterns. International Review of Research in Open \& Distance Learning, 10(6).

This work is licensed under a Creative Commons Attribution 4.0 International License. 
Trends in Distance Education Research: A Content Analysis of Journals 2009-2013

Bozkurt, Akgun-Ozbek, Yilmazel, Erdogdu, Ucar, Guler, Sezgin, Karadeniz, Sen-Ersoy, Goksel-Canbek, Dincer, Ari, and Aydin

\section{Appendix A}

\section{List of the most cited authors $(\mathrm{N}=105)$}

\begin{tabular}{|c|c|c|c|c|c|c|c|c|}
\hline$R^{*}$ & $\mathrm{~F}^{* *}$ & Author & $R^{*}$ & $\mathrm{~F}^{* *}$ & Author & $R^{*}$ & $\mathrm{~F}^{* *}$ & Author \\
\hline 1 & 520 & GARRISON, D.R. & 34 & 51 & JONASSEN, D.H. & 50 & 35 & KOP, R. \\
\hline 2 & 405 & ANDERSON, T. & 35 & 49 & BOROKHOVSKI, E. & 50 & 35 & McISAAC, M.S. \\
\hline 3 & 208 & MOORE, M.G. & 36 & 48 & CAVANAUGH, C. & 50 & 35 & OLIVER, R. \\
\hline 4 & 207 & ARCHER, W. & 36 & 48 & ICE, $P$. & 51 & 34 & CONRAD, D. \\
\hline 5 & 145 & SEAMAN, J. & 36 & 48 & HOLMBERG, B. & 51 & 34 & HARA, N. \\
\hline 6 & 135 & SHEA, P. & 37 & 47 & CASPI, A. & 51 & 34 & LAURILLARD, D. \\
\hline 7 & 129 & ROURKE, L. & 37 & 47 & CRESWELLJ, W. & 51 & 34 & LAVE, J. \\
\hline 8 & 129 & SWAN, K. & 38 & 46 & ROBLYER, M.D. & 51 & 34 & TINTO, V. \\
\hline 9 & 109 & ROVAI, A.P. & 38 & 46 & UNESCO & 52 & 33 & LAN, W.Y. \\
\hline 10 & 105 & ALLEN, I.E. & 39 & 45 & BROWN, J.S. & 52 & 33 & PICKETT, A.M. \\
\hline 11 & 103 & SIEMENS, G. & 40 & 44 & RICHARDSON, J.C. & 52 & 33 & RICHARDSON, J.T.E. \\
\hline 12 & 102 & DOWNES, S. & 41 & 43 & GORSKY, P. & 52 & 33 & VELETSIANOS, G. \\
\hline 13 & 101 & BONK, C.J. & 41 & 43 & GRAHAM, C.R. & 53 & 32 & BATES, A.W. \\
\hline 14 & 100 & GUNAWARDENA, C.N. & 41 & 43 & MASON, R. & 53 & 32 & HILL, J.R. \\
\hline 15 & 94 & ARBAUGH, J.B. & 41 & 43 & MURPHY, E. & 53 & 32 & KELLER, J.M. \\
\hline 16 & 90 & WENGER, E. & 42 & 42 & MAYER, R.E. & 53 & 32 & MISHRA, P. \\
\hline 17 & 88 & CLEVELAND, INNES, M & 43 & 41 & BERGE, Z. & 53 & 32 & PERRATON, H. \\
\hline 18 & 81 & WILEY, D. & 43 & 41 & DEWEY, J. & 53 & 32 & PINTRICH, P.R. \\
\hline 19 & 79 & KANUKA, H. & 43 & 41 & KIRSCHNER, P.A. & 53 & 32 & TAIT, A. \\
\hline 20 & 77 & SALMON, G. & 44 & 41 & SABA, F. & 53 & 32 & TAYLOR, J. \\
\hline 21 & 68 & CONOLE, G. & 45 & 40 & RUMBLE, G. & 54 & 31 & COLLIS, B. \\
\hline 21 & 68 & PRATT, K. & 45 & 40 & TU, C.H. & 54 & 31 & JOHNSON, D.W. \\
\hline 22 & 66 & HILTZ, S.R. & 45 & 40 & ZIMMERMAN, B.J. & 54 & 31 & OLIVER, M. \\
\hline 23 & 65 & ABRAMI, P.C. & 46 & 39 & CLARK, T. & 54 & 31 & POTTER, C.S. \\
\hline 24 & 63 & SWELLER, J. & 46 & 39 & LINCOLN, Y.S. & 55 & 30 & CHICKERING, A.W. \\
\hline 25 & 62 & PALLOFF, R.M. & 46 & 39 & MCLOUGHLIN, C. & 55 & 30 & DANIEL, J. \\
\hline 26 & 61 & BARBOUR, M.K. & 46 & 39 & PICKETT, A. & 55 & 30 & FAHY, P.J. \\
\hline 26 & 61 & BERNARD, R.M. & 47 & 38 & DAVIS, F.D. & 55 & 30 & MEANS, B. \\
\hline 27 & 58 & BERGE, Z.L. & 47 & 38 & PICCIANO, A.G. & 55 & 30 & NACHMIAS, R. \\
\hline 28 & 57 & KEARSLEY, G. & 48 & 37 & SHARPLES, M. & 55 & 30 & PAAS, F. \\
\hline 29 & 56 & DRON, J. & 49 & 36 & LIU, X. & 55 & 30 & PAULSEN, M.F. \\
\hline 30 & 54 & BANDURA, A. & 49 & 36 & LOU, Y. & 55 & 30 & PETERS, O. \\
\hline 31 & 54 & KEEGAN, D. & 49 & 36 & REEVES, T.C. & 55 & 30 & PRENSKY, M. \\
\hline 32 & 52 & SIMPSON, O. & 49 & 36 & SWAN, K.P. & 55 & 30 & TRAXLER, J. \\
\hline 33 & 51 & VYGOTSKY, LS. & 50 & 35 & HURD, S. & 55 & 30 & VAUGHAN, N. \\
\hline
\end{tabular}

This work is licensed under a Creative Commons Attribution 4.0 International License. 
Trends in Distance Education Research: A Content Analysis of Journals 2009-2013

Bozkurt, Akgun-Ozbek, Yilmazel, Erdogdu, Ucar, Guler, Sezgin, Karadeniz, Sen-Ersoy, Goksel-Canbek, Dincer, Ari, and Aydin

\section{Appendix B}

\section{The reference list of most cited works}

\begin{tabular}{|c|c|c|c|}
\hline$R^{*}$ & $F * *$ & $T \cdots$ & References \\
\hline 1 & 62 & A & $\begin{array}{l}\text { Garrison, D. R., Anderson, T., \& Archer, W. (1999). Critical inquiry in a text-based environment: Computer conferencing } \\
\text { in higher education. The internet and higher education, 2(2), 87-105. }\end{array}$ \\
\hline 2 & 53 & B & Vygotsky, L. S. (1980). Mind in society: The development of higher psychological processes. Harvard University Press. \\
\hline 3 & 51 & B & Moore, M. G. \& Kearsley, G. (1996). Distance education: A Systems View. Canada: Wadsworth. \\
\hline 4 & 43 & A & Moore, M. G. (1989). Editorial: Three types of interaction. American Journal of Distance Education, 3(2), 1-7. \\
\hline 5 & 40 & $\mathrm{C}$ & $\begin{array}{l}\text { Moore, M. G. (1993). Theory of transactional distance. In D. Keegan (Ed.), Theoretical principles of distance education. } \\
\text { (p 22-38) New York: Routledge. }\end{array}$ \\
\hline 6 & 35 & B & Jean. Lave, \& Wenger, E. (1991). Situated learning: Legitimate peripheral participation. Cambridge University Press. \\
\hline 6 & 35 & B & Patton, M. Q. (1980). Qualitative evaluation and research methods. SAGE Publications, inc. \\
\hline 7 & 34 & $\mathrm{R}$ & $\begin{array}{l}\text { Means, B., Toyama, Y., Murphy, R., Bakia, M., \& Jones, K. (2009). Evaluation of Evidence-Based Practices in Online } \\
\text { Learning: A Meta-Analysis and Review of Online Learning Studies. US Department of Education. }\end{array}$ \\
\hline 7 & 34 & $\mathrm{R}$ & $\begin{array}{l}\text { Allen, I. E., \& Seaman, J. (2008). Staying the Course: Online Education in the United States, 2008. Sloan Consortium, } \\
\text { Newburyport. }\end{array}$ \\
\hline 7 & 34 & A & $\begin{array}{l}\text { Garrison, D. R., \& Arbaugh, J. B. (2007). Researching the community of inquiry framework: Review, issues, and future } \\
\text { directions. The Internet and Higher Education, 10(3), 157-172. }\end{array}$ \\
\hline 7 & 34 & A & $\begin{array}{l}\text { Anderson, T., Liam, R., Garrison, D. R., \& Archer, W. (2001). Assessing teacher presence in a computer conferencing } \\
\text { context. Journal of Asynchronous Learning Networks, 5(2), 1-17. }\end{array}$ \\
\hline 7 & 34 & B & Salmon, G. (2000). E-moderating: The key to teaching and learning online. Psychology Press. \\
\hline 8 & 33 & B & $\begin{array}{l}\text { Garrison, D. R., \& Anderson, T. (2003). E-learning in the 21st century: A framework for research and practice. Taylor \& } \\
\text { Francis. }\end{array}$ \\
\hline 9 & 32 & W & $\begin{array}{l}\text { Siemens, G. (2004). Connectivism: A learning theory for the digital age. Retrieved from } \\
\text { http://www.elearnspace.org/Articles/connectivism.htm }\end{array}$ \\
\hline 10 & 31 & B & Wenger, E. (1998). Communities of practice: Learning, meaning, and identity. Cambridge University Press. \\
\hline 11 & 30 & $\mathrm{R}$ & $\begin{array}{l}\text { Allen, I. E., \& Seaman, J. (2010). Learning on Demand: Online Education in the United States, 2009. Sloan Consortium, } \\
\text { Newburyport. }\end{array}$ \\
\hline 12 & 28 & $\mathrm{R}$ & $\begin{array}{l}\text { Watson, J., Gemin, B., Ryan, J., \& Wicks, M. (2009). Keeping Pace with K-12 Online Learning: An Annual Review of } \\
\text { State-Level Policy and Practice, 2009. Evergreen Education Group. }\end{array}$ \\
\hline 12 & 28 & A & $\begin{array}{l}\text { Tallent-Runnels, M. K., Thomas, J. A., Lan, W. Y., Cooper, S., Ahern, T. C., Shaw, S. M., \& Liu, X. (2006). Teaching } \\
\text { courses online: A review of the research. Review of educational research, 76(1), 93-135. }\end{array}$ \\
\hline 12 & 28 & A & $\begin{array}{l}\text { Garrison, D. R., Anderson, T., \& Archer, W. (2001). Critical thinking, cognitive presence, and computer conferencing in } \\
\text { distance education. American Journal of distance education, 15(1), 7-23. }\end{array}$ \\
\hline 12 & 28 & B & Yin, R. K. (1984). Case study research: Design and methods. SAGE Publications, inc. \\
\hline 13 & 27 & A & $\begin{array}{l}\text { Garrison, D. R., \& Cleveland-Innes, M. (2005). Facilitating cognitive presence in online learning: Interaction is not } \\
\text { enough. The American Journal of Distance Education, 19(3), 133-148. }\end{array}$ \\
\hline 14 & 24 & A & $\begin{array}{l}\text { Downes, S. (2007). Models for sustainable open educational resources. Interdisciplinary Journal of Knowledge and } \\
\text { Learning Objects, 3, 29-44. }\end{array}$ \\
\hline 15 & 23 & B & $\begin{array}{l}\text { Organisation for Economic Co-operation and Development. (2007). Giving knowledge for free: The emergence of open } \\
\text { educational resources. OECD Publishing. }\end{array}$ \\
\hline 16 & 22 & $\mathrm{R}$ & $\begin{array}{l}\text { Allen, I. E., \& Seaman, J. (2007). Online Nation: Five Years of Growth in Online Learning. Sloan Consortium, } \\
\text { Newburyport. }\end{array}$ \\
\hline 17 & 22 & A & $\begin{array}{l}\text { Carr, S. (2000). As distance education comes of age, the challenge is keeping the students. The Chronicle of Higher } \\
\text { Education, 46(23), A39-A41. }\end{array}$ \\
\hline 18 & 21 & A & $\begin{array}{l}\text { Bernard, R. M., Abrami, P. C., Lou, Y., Borokhovski, E., Wade, A., Wozney, L., Wallet, P. A., Fiset, M. \& Huang, B. } \\
\text { (2004). How does distance education compare with classroom instruction? A meta-analysis of the empirical } \\
\text { literature. Review of educational research, 74(3), 379-439. }\end{array}$ \\
\hline 18 & 21 & A & $\begin{array}{l}\text { Picciano, A. G. (2002). Beyond student perceptions: Issues of interaction, presence, and performance in an online } \\
\text { course. Journal of Asynchronous learning networks, } 6(1), 21-40 \text {. }\end{array}$ \\
\hline 18 & 21 & B & $\begin{array}{l}\text { Glaser, B. G., \& Strauss, A. L. (1967). The discovery of grounded theory: Strategies for qualitative research. Transaction } \\
\text { Publishers. }\end{array}$ \\
\hline 19 & 20 & A & $\begin{array}{l}\text { Anderson, T., \& Dron, J. (2011). Three Generations of Distance Education Pedagogy. International Review of Research } \\
\text { in Open \& Distance Learning, 12(3). }\end{array}$ \\
\hline 19 & 20 & A & $\begin{array}{l}\text { Swan, K., \& Shih, L. F. (2005). On the nature and development of social presence in online course discussions. Journal of } \\
\text { Asynchronous Learning Networks, } 9(3), 115-136 \text {. }\end{array}$ \\
\hline 19 & 20 & A & $\begin{array}{l}\text { Richardson, J., \& Swan, K. (2003). An examination of social presence in online learning: Students' perceived learning } \\
\text { and satisfaction. Journal of Asynchronous Learning Networks, 7(1), 68-88. }\end{array}$ \\
\hline 19 & 20 & A & Prensky, M. (2001). Digital natives, digital immigrants part 1. On the horizon,9(5), 1-6. \\
\hline
\end{tabular}

This work is licensed under a Creative Commons Attribution 4.0 International License. 
Trends in Distance Education Research: A Content Analysis of Journals 2009-2013 Bozkurt, Akgun-Ozbek, Yilmazel, Erdogdu, Ucar, Guler, Sezgin, Karadeniz, Sen-Ersoy, Goksel-Canbek, Dincer, Ari, and Aydin

\begin{tabular}{|c|c|c|c|}
\hline$R^{*}$ & $F * *$ & $T * * *$ & References \\
\hline 20 & 19 & A & $\begin{array}{l}\text { Anderson, T. (2003). Getting the mix right again: An updated and theoretical rationale for interaction. The International } \\
\text { Review of Research in Open and Distance Learning, 4(2). }\end{array}$ \\
\hline 20 & 19 & B & Salmon, G. (2002). E-tivities: The key to active online learning. Psychology Press. \\
\hline 20 & 19 & A & $\begin{array}{l}\text { Gunawardena, C. N., \& Zittle, F. J. (1997). Social presence as a predictor of satisfaction within a computer-mediated } \\
\text { conferencing environment. American Journal of Distance Education, 11(3), 8-26. }\end{array}$ \\
\hline 20 & 19 & B & $\begin{array}{l}\text { Kolb, D. A. (1984). Experiential learning: Experience as the source of learning and development (Vol. 1). Englewood } \\
\text { Cliffs, NJ: Prentice-Hall. }\end{array}$ \\
\hline 21 & 18 & B & $\begin{array}{l}\text { Anderson, L. W., \& Krathwohl, D. R. (Eds.). (2001). A taxonomy for learning, teaching, and assessing: A revision of } \\
\text { Bloom's taxonomy of educational objectives. New York: Longman }\end{array}$ \\
\hline 21 & 18 & A & $\begin{array}{l}\text { Shea, P., Sau Li, C., \& Pickett, A. (2006). A study of teaching presence and student sense of learning community in fully } \\
\text { online and web-enhanced college courses. The Internet and Higher Education, 9(3), 175-190. }\end{array}$ \\
\hline 21 & 18 & B & Palloff, R. M., \& Pratt, K. (1999). Building learning communities in cyberspace. San Francisco: Jossey-Bass Publishers. \\
\hline 21 & 18 & B & Rogers, E. M. (1962). Diffusion of innovations. Simon and Schuster. \\
\hline 22 & 17 & $\mathrm{R}$ & $\begin{array}{l}\text { Allen, I. E., \& Seaman, J. (2007). Making the grade: Online education in the United States, 2006. Sloan Consortium, } \\
\text { Newburyport. }\end{array}$ \\
\hline 22 & 17 & $\mathrm{R}$ & $\begin{array}{l}\text { Atkins, D. E., Brown, J. S., \& Hammond, A. L. (2007). A review of the open educational resources (OER) movement: } \\
\text { Achievements, challenges, and new opportunities (pp. 1-84). Report to The William and Flora Hewlett Foundation }\end{array}$ \\
\hline 22 & 17 & A & $\begin{array}{l}\text { Garrison, D. R., \& Kanuka, H. (2004). Blended learning: Uncovering its transformative potential in higher education. The } \\
\text { internet and higher education,7(2), 95-105. }\end{array}$ \\
\hline 22 & 17 & B & Cohen, L., Manion, L., \& Morrison, K. (2000). Research Methods in Education. London: Routledge Falmer. \\
\hline 22 & 17 & B & Schön, D. A. (1983). The reflective practitioner: How professionals think in action. New York: Basic Books. \\
\hline 23 & 16 & A & $\begin{array}{l}\text { Beldarrain, Y. (2006). Distance education trends: Integrating new technologies to foster student interaction and } \\
\text { collaboration. Distance education, } 27(2), 139-153 .\end{array}$ \\
\hline 23 & 16 & B & $\begin{array}{l}\text { Palloff, R. M., \& Pratt, K. (1999). Building online learning communities: Effective strategies for the virtual classroom. } \\
\text { John Wiley \& Sons. }\end{array}$ \\
\hline 23 & 16 & B & $\begin{array}{l}\text { Creswell, J. W. (1994). Research design: Qualitative, quantitative, and mixed methods approaches. SAGE Publications, } \\
\text { inc. }\end{array}$ \\
\hline 23 & 16 & A & $\begin{array}{l}\text { Brown, J. S., Collins, A., \& Duguid, P. (1989). Situated cognition and the culture of learning. Educational } \\
\text { researcher, 18(1), 32-42. }\end{array}$ \\
\hline 23 & 16 & B & Short, J., Williams, E., \& Christie, B. (1976). The social psychology of telecommunications. New York: Wiley \\
\hline 24 & 15 & A & $\begin{array}{l}\text { Hillman, D. C., Willis, D. J., \& Gunawardena, C. N. (1994). Learner-interface interaction in distance education: An } \\
\text { extension of contemporary models and strategies for practitioners. American Journal of Distance Education, 8(2), 30-42. }\end{array}$ \\
\hline 25 & 14 & $\mathrm{R}$ & $\begin{array}{l}\text { OLCOS. (2007). Open Educational Practices and Resources: OLCOS Roadmap 2012. Austria: OLCOS Project } \\
\text { Consortium. }\end{array}$ \\
\hline 25 & 14 & A & $\begin{array}{l}\text { Muilenburg, L. Y., \& Berge, Z. L. (2005). Student barriers to online learning: A factor analytic study. Distance } \\
\text { education, 26(1), 29-48. }\end{array}$ \\
\hline 25 & 14 & A & $\begin{array}{l}\text { Cavanaugh, C., Gillan, K. J., Kromrey, J., Hess, M., \& Blomeyer, R. (2004). The Effects of Distance Education on K-12 } \\
\text { Student Outcomes: A Meta-Analysis. Learning Point Associates/North Central Regional Educational Laboratory } \\
\text { (NCREL). }\end{array}$ \\
\hline 25 & 14 & A & $\begin{array}{l}\text { Jung, I., Choi, S., Lim, C., \& Leem, J. (2002). Effects of different types of interaction on learning achievement, } \\
\text { satisfaction and participation in web-based instruction. Innovations in Education and Teaching International, 39(2), 153- } \\
162 .\end{array}$ \\
\hline 25 & 14 & B & $\begin{array}{l}\text { Laurillard, D. (2002). Rethinking university teaching: A conversational framework for the effective use of learning } \\
\text { technologies. Routledge. }\end{array}$ \\
\hline 25 & 14 & A & $\begin{array}{l}\text { Tu, C. H., \& McIsaac, M. (2002). The relationship of social presence and interaction in online classes. The American } \\
\text { journal of distance education, 16(3), 131-150. }\end{array}$ \\
\hline 25 & 14 & A & $\begin{array}{l}\text { Hara, N., Bonk, C. J., \& Angeli, C. (2000). Content analysis of online discussion in an applied educational psychology } \\
\text { course. Instructional Science, 28(2), 115-152. }\end{array}$ \\
\hline 25 & 14 & A & $\begin{array}{l}\text { Davis, F. D. (1989). Perceived usefulness, perceived ease of use, and user acceptance of information technology. MIS } \\
\text { quarterly, 319-340. }\end{array}$ \\
\hline 25 & 14 & B & Lincoln, Y. S., \& Guba, E. G. (1985). Naturalist inquiry. Beverly Hills, CA: SAGE Publications, inc. \\
\hline 26 & 13 & B & $\begin{array}{l}\text { Garrison, D. R., \& Vaughan, N. D. (2008). Blended learning in higher education: Framework, principles, and guidelines. } \\
\text { John Wiley \& Sons. }\end{array}$ \\
\hline 26 & 13 & B & Moore, M. G. (Ed.). (2003). Handbook of distance education. Routledge. \\
\hline 26 & 13 & $\mathrm{R}$ & $\begin{array}{l}\text { Tabs, E. D., Waits, T., \& Lewis, L. (2003). Distance education at degree-granting postsecondary institutions: 2000-2001. } \\
\text { Washington, DC: US Department of Education. }\end{array}$ \\
\hline
\end{tabular}

This work is licensed under a Creative Commons Attribution 4.0 International License. 
Trends in Distance Education Research: A Content Analysis of Journals 2009-2013 Bozkurt, Akgun-Ozbek, Yilmazel, Erdogdu, Ucar, Guler, Sezgin, Karadeniz, Sen-Ersoy, Goksel-Canbek, Dincer, Ari, and Aydin

\begin{tabular}{|c|c|c|c|}
\hline$R^{*}$ & $F * *$ & $T * * *$ & References \\
\hline 26 & 13 & A & $\begin{array}{l}\text { Rovai, A. P. (2002). Development of an instrument to measure classroom community. The Internet and Higher } \\
\text { Education, 5(3), 197-211. }\end{array}$ \\
\hline 26 & 13 & B & $\begin{array}{l}\text { Palloff, R. M., \& Pratt, K. (2001). Lessons from the cyberspace classroom: The realities of online teaching. John Wiley \& } \\
\text { Sons. }\end{array}$ \\
\hline 26 & 13 & A & $\begin{array}{l}\text { Garrison, R. (2000). Theoretical challenges for distance education in the 21st century: A shift from structural to } \\
\text { transactional issues. The International Review of Research in Open and Distance Learning, 1(1). }\end{array}$ \\
\hline 26 & 13 & B & Bates, A. T. (1995). Technology, e-learning and distance education. Routledge. \\
\hline 26 & 13 & B & Stake, R. E. (1995). The art of case study research. SAGE Publications, inc. \\
\hline 26 & 13 & $\mathrm{C}$ & $\begin{array}{l}\text { Henri, F. (1992). Computer conferencing and content analysis. In A. Kaye (Ed.), Collaborative learning through } \\
\text { computer conferencing: The Najaden papers (pp. 117-136). Berlin: Springer-Verlag. }\end{array}$ \\
\hline 26 & 13 & $\mathrm{~B}$ & $\begin{array}{l}\text { Engeström, Y. (1987). Learning by expanding: An activity-theoretical approach to developmental research. Helsinki, } \\
\text { Finland: Orienta-Konsultit. }\end{array}$ \\
\hline 27 & 12 & $\mathrm{R}$ & $\begin{array}{l}\text { Allen, I. E., \& Seaman, J. (2010). Class Differences: Online Education in the United States, 2010. Sloan Consortium, } \\
\text { Newburyport. }\end{array}$ \\
\hline 27 & 12 & A & $\begin{array}{l}\text { Barbour, M. K., \& Reeves, T. C. (2009). The reality of virtual schools: A review of the literature. Computers \& } \\
\text { Education, 52(2), 402-416. }\end{array}$ \\
\hline 27 & 12 & A & $\begin{array}{l}\text { Arbaugh, J. B., Cleveland-Innes, M., Diaz, S. R., Garrison, D. R., Ice, P., Richardson, J. C., \& Swan, K. P. (2008). } \\
\text { Developing a community of inquiry instrument: Testing a measure of the community of inquiry framework using a multi- } \\
\text { institutional sample. The Internet and Higher Education, 11(3), 133-136. }\end{array}$ \\
\hline 27 & 12 & A & $\begin{array}{l}\text { Caswell, T., Henson, S., Jensen, M., \& Wiley, D. (2008). Open Educational Resources: Enabling universal } \\
\text { education. International Review of Research in Open \& Distance Learning, 9(1). }\end{array}$ \\
\hline 27 & 12 & $\mathrm{R}$ & $\begin{array}{l}\text { Clark, T. (2001). Virtual Schools: Trends and Issues. A Study of Virtual Schools in the United States. San Francisco, CA: } \\
\text { Western Regional Educational Laboratories. }\end{array}$ \\
\hline 27 & 12 & B & Mayer, R. E. (2001). Multimedia learning. Cambridge University Press. \\
\hline 27 & 12 & A & $\begin{array}{l}\text { Rourke, L., Anderson, T., Garrison, D. R., \& Archer, W. (2001). Methodological issues in the content analysis of } \\
\text { computer conference transcripts. International Journal of Artificial Intelligence in Education (IJAIED), 12, 8-22. }\end{array}$ \\
\hline 27 & 12 & B & $\begin{array}{l}\text { Simonson, M., Smaldino, S., Albright, M., \& Zvacek, S. (2000). Teaching and Learning at a Distance: Foundations of } \\
\text { Distance Education. Upper Saddle River, NJ: Merrill. }\end{array}$ \\
\hline 27 & 12 & A & $\begin{array}{l}\text { Bullen, M. (1999). What's the Difference: A Review of Contemporary Research on the Effectiveness of Distance } \\
\text { Learning in Higher Education by Ronald Phipps and Jamie Merisotis. The Journal of Distance Education, 14(1), 109-112. }\end{array}$ \\
\hline 27 & 12 & BL & $\begin{array}{l}\text { Chickering, A. W., \& Gamson, Z. F. (1987). Seven principles for good practice in undergraduate education. AAHE } \\
\text { bulletin, 3, 7. }\end{array}$ \\
\hline 27 & 12 & $\mathrm{C}$ & $\begin{array}{l}\text { Anderson, T., \& Garrison, D. R. (1998). Learning in a networked world: New roles and responsibilities. In C.C. Gibson } \\
\text { (ed.), Distance Learners in Higher Education: Institutional responses for quality outcomes (pp.97-112). Madison, Wi.: } \\
\text { Atwood. }\end{array}$ \\
\hline 27 & 12 & B & $\begin{array}{l}\text { Creswell, J. W. (1998). Qualitative inquiry and research design: Choosing among five approaches. SAGE Publications, } \\
\text { inc. }\end{array}$ \\
\hline 27 & 12 & C & $\begin{array}{l}\text { McIsaac, M.S. \& Gunawardena, C.N. (1996). Distance Education. In D.H. Jonassen, ed. Handbook of research for } \\
\text { educational communications and technology: a project of the Association for Educational Communications and } \\
\text { Technology. 403-437. New York: Simon \& Schuster Macmillan. }\end{array}$ \\
\hline 27 & 12 & B & $\begin{array}{l}\text { Corbin, J., \& Strauss, A. (Eds.). (1990). Basics of qualitative research: Techniques and procedures for developing } \\
\text { grounded theory. SAGE Publications, inc. }\end{array}$ \\
\hline 27 & 12 & B & Borg, W. R., \& Gall, M. D. (1979). Educational research: An introduction. New York: Longman. \\
\hline 28 & 11 & A & $\begin{array}{l}\text { Mishra, P., \& Koehler, M. (2006). Technological pedagogical content knowledge: A framework for teacher } \\
\text { knowledge. The Teachers College Record, 108(6), 1017-1054. }\end{array}$ \\
\hline 28 & 11 & A & $\begin{array}{l}\text { Zhao, Y., Lei, J., Yan, B., Lai, C., \& Tan, S. (2005). What makes the difference? A practical analysis of research on the } \\
\text { effectiveness of distance education. The Teachers College Record, 107(8), 1836-1884. }\end{array}$ \\
\hline 28 & 11 & A & $\begin{array}{l}\text { Rovai, A. P., \& Jordan, H. M. (2004). Blended Learning and Sense of Community: A Comparative Analysis with } \\
\text { Traditional and Fully Online Graduate Courses. International Review of Research in Open \& Distance Learning, 5(2). }\end{array}$ \\
\hline 28 & 11 & A & Simpson, O. (2004). The impact on retention of interventions to support distance learning students. Open Learning, 19(1). \\
\hline 28 & 11 & A & $\begin{array}{l}\text { Meyer, K. A. (2003). Face-to-face versus threaded discussions: The role of time and higher-order thinking. Journal of } \\
\text { Asynchronous Learning Networks, 7(3), 55-65. }\end{array}$ \\
\hline 28 & 11 & A & $\begin{array}{l}\text { Swan, K. (2001). Virtual interaction: Design factors affecting student satisfaction and perceived learning in asynchronous } \\
\text { online courses. Distance education, 22(2), 306-331. }\end{array}$ \\
\hline 28 & 11 & $\mathrm{R}$ & $\begin{array}{l}\text { Ronald, P., \& Jamie, M. (2000). Quality on the line-Benchmarks for success in Internet-based distance education. The } \\
\text { Institute for Higher Education Policy. }\end{array}$ \\
\hline 28 & 11 & B & Perraton, H. (2000). Open and distance learning in the developing world. Routledge. \\
\hline
\end{tabular}

This work is licensed under a $\underline{\text { Creative Commons Attribution } 4.0 \text { International License. }}$ 
Trends in Distance Education Research: A Content Analysis of Journals 2009-2013 Bozkurt, Akgun-Ozbek, Yilmazel, Erdogdu, Ucar, Guler, Sezgin, Karadeniz, Sen-Ersoy, Goksel-Canbek, Dincer, Ari, and Aydin

\begin{tabular}{|c|c|c|c|}
\hline$R^{*}$ & $F * *$ & $T * * *$ & References \\
\hline 28 & 11 & A & $\begin{array}{l}\text { Gunawardena, C. N. (1995). Social presence theory and implications for interaction and collaborative learning in } \\
\text { computer conferences. International journal of educational telecommunications, 1(2), 147-166. }\end{array}$ \\
\hline 28 & 11 & B & Biggs, J., \& Tang, C. (1999). Teaching for quality learning at university. McGraw-Hill International. \\
\hline 28 & 11 & B & Bandura, A. (1997). Self-efficacy: The exercise of control. Macmillan. \\
\hline 28 & 11 & B & Tabachnick, B. G., and Fidell, L. S. (1996). Using Multivariate Statistics. Boston : Allyn and Bacon. \\
\hline 28 & 11 & $\mathrm{~B}$ & Keegan, D. (1986). Foundations of distance education. Psychology Press. \\
\hline 28 & 11 & A & $\begin{array}{l}\text { Tinto, V. (1975). Dropout from higher education: A theoretical synthesis of recent research. Review of educational } \\
\text { research, 45(1), 89-125. }\end{array}$ \\
\hline 29 & 10 & $\mathrm{P}$ & $\begin{array}{l}\text { Mackness, J., Mak, S., \& Williams, R. (2010). The ideals and reality of participating in a MOOC. In Networked Learning } \\
\text { Conference (pp. 266-275). University of Lancaster. }\end{array}$ \\
\hline 29 & 10 & A & Bissell, A. N. (2009). Permission granted: open licensing for educational resources. Open Learning, 24(1), 97-106. \\
\hline 29 & 10 & B & $\begin{array}{l}\text { Iiyoshi, T., \& Kumar, M. V. (Eds.). (2008). Opening up education: The collective advancement of education through } \\
\text { open technology, open content, and open knowledge. MIT Press. }\end{array}$ \\
\hline 29 & 10 & A & $\begin{array}{l}\text { Rice, K. L. (2006). A Comprehensive Look at Distance Education in the K-12 Context. Journal of Research on } \\
\text { Technology in Education, 38(4). }\end{array}$ \\
\hline 29 & 10 & A & $\begin{array}{l}\text { Young, S. (2006). Student views of effective online teaching in higher education. The American Journal of Distance } \\
\text { Education, 20(2), 65-77. }\end{array}$ \\
\hline 29 & 10 & A & $\begin{array}{l}\text { Shea, P., Li, C. S., Swan, K., \& Pickett, A. (2005). Developing learning community in online asynchronous college } \\
\text { courses: The role of teaching presence. Journal of Asynchronous Learning Networks, 9(4), 59-82. }\end{array}$ \\
\hline 29 & 10 & A & $\begin{array}{l}\text { Rourke, L., Anderson, T., Garrison, D. R., \& Archer, W. (2004). Assessing Social Presence in Asynchronous Text-based, } \\
\text { Computer Conferencing. Journal of distance education, 14(2). }\end{array}$ \\
\hline 29 & 10 & B & Bates, T., \& Poole, G. (2003). Effective teaching with technology in higher education. San Francisco: Jossey-Bass. \\
\hline 29 & 10 & A & $\begin{array}{l}\text { Allen, M., Bourhis, J., Burrell, N., \& Mabry, E. (2002). Comparing student satisfaction with distance education to } \\
\text { traditional classrooms in higher education: A meta-analysis. The American Journal of Distance Education,16(2), 83-97. }\end{array}$ \\
\hline 29 & 10 & A & $\begin{array}{l}\text { Rovai, A. P. (2002). Building sense of community at a distance. The International Review of Research in Open and } \\
\text { Distance Learning, 3(1). }\end{array}$ \\
\hline 29 & 10 & A & $\begin{array}{l}\text { Rovai, A. P. (2002). Sense of community, perceived cognitive learning, and persistence in asynchronous learning } \\
\text { networks. The Internet and Higher Education, 5(4), 319-332. }\end{array}$ \\
\hline 29 & 10 & A & $\begin{array}{l}\text { Curtis, D. D., \& Lawson, M. J. (2001). Exploring collaborative online learning. Journal of Asynchronous learning } \\
\text { networks, 5(1), 21-34. }\end{array}$ \\
\hline 29 & 10 & $\mathrm{C}$ & $\begin{array}{l}\text { Jonassen, D. (1999) Designing constructivist learning environments. In C.M. Reigeluth (Ed.), Instructional design } \\
\text { theories and models: A new paradigm of instructional theory (Vol. II) (pp. 215-239). Mahwah, NJ: Lawrence Erlbaum } \\
\text { Associates. }\end{array}$ \\
\hline 29 & 10 & B & $\begin{array}{l}\text { Russell, T. L. (1999). No Significant Difference Phenomenon. Chapel Hill, NC: Office of Instructional } \\
\text { Telecommunications, North Carolina University }\end{array}$ \\
\hline 29 & 10 & A & $\begin{array}{l}\text { Gunawardena, C. N., Lowe, C. A., \& Anderson, T. (1997). Analysis of a global online debate and the development of an } \\
\text { interaction analysis model for examining social construction of knowledge in computer conferencing. Journal of } \\
\text { educational computing research, 17(4), 397-431. }\end{array}$ \\
\hline 29 & 10 & A & $\begin{array}{l}\text { Berge, Z. L. (1995). Facilitating Computer Conferencing: Recommendations from the Field. Educational } \\
\text { Technology, 35(1), 22-30. }\end{array}$ \\
\hline 29 & 10 & A & $\begin{array}{l}\text { Wagner, E. D. (1994). In support of a functional definition of interaction. American Journal of Distance Education, 8(2), } \\
6-29 .\end{array}$ \\
\hline 29 & 10 & B & $\begin{array}{l}\text { Bandura, A. (1986). Social foundations of thought and action: A cognitive social theory. Englewood Cliffs, New York: } \\
\text { Pretince Hall. }\end{array}$ \\
\hline 29 & 10 & $\mathrm{~B}$ & Bandura, A. (1977). Social learning theory. Englewood Cliffs: Pretince Hall. \\
\hline
\end{tabular}

(c) Bozkurt, Akgun-Ozbek, Yilmazel, Erdogdu, Ucar, Guler, Sezgin, Karadeniz, Sen-Ersoy, GokselCanbek, Dincer, Ari, and Aydin

\section{Athabasca University $\mathbf{A}$}

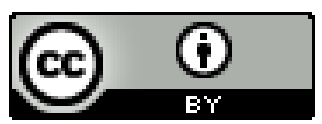

This work is licensed under a Creative Commons Attribution 4.0 International License. 